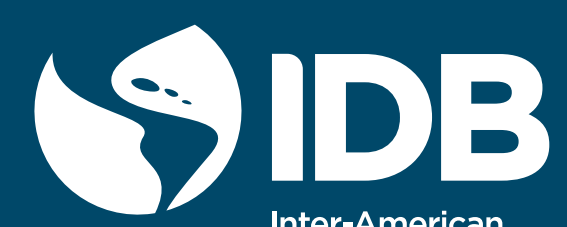

\title{
The Use of Corruption Indicators in Sovereign Ratings
}

Prepared for the Innovation in Citizen Services Division by:

Ugo Panizza 



\section{The Use of Corruption Indicators in Sovereign Ratings}

Prepared for the Innovation in Citizen Services

Division by:

Ugo Panizza 
Cataloging-in-Publication data provided by the

Inter-American Development Bank

Felipe Herrera Library

Panizza, Ugo.

The use of corruption indicators in sovereign ratings / Ugo Panizza.

p. cm. - (IDB Technical Note ; 1318)

Includes bibliographic references.

1. Country risk-Ratings and rankings. 2. Risk assessment-Economic policy.

3.Corruption. I. Inter-American Development Bank. Institutional Capacity of State

Division. IV. Title. V. Series.

IDB-TN-1318

http://www.iadb.org

Copyright $\odot 2017$ Inter-American Development Bank. This work is licensed under a Creative Commons IGO 3.0 Attribution-NonCommercial-NoDerivatives (CC-IGO BY-NC-ND 3.0 IGO) license (http://creativecommons.org/ licenses/by-nc-nd/3.0/igo/legalcode) and may be reproduced with attribution to the IDB and for any non-commercial purpose. No derivative work is allowed.

Any dispute related to the use of the works of the IDB that cannot be settled amicably shall be submitted to arbitration pursuant to the UNCITRAL rules. The use of the IDB's name for any purpose other than for attribution, and the use of IDB's logo shall be subject to a separate written license agreement between the IDB and the user and is not authorized as part of this CC-IGO license.

Note that link provided above includes additional terms and conditions of the license.

The opinions expressed in this publication are those of the authors and do not necessarily reflect the views of the Inter-American Development Bank, its Board of Directors, or the countries they represent.

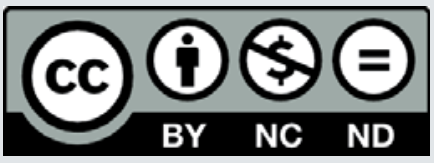




\section{ABSTRACT*}

This paper studies the relationship between sovereign ratings and corruption indicators. The paper first shows a strong correlation between ratings issued by the three main rating agencies (Standard \& Poor's, Moody's, and Fitch) and three commonly used corruption indicators. This correlation is robust to controlling for the fact that corruption is also correlated with level of development, amount of government debt, the current account balance, and an indicator of macroeconomic instability. However, the conditional correlation between corruption and sovereign ratings is not generally robust to controlling for the fact that corruption is correlated with other governance indicators. Moreover, using standard statistical techniques it is not possible to establish whether the observed correlation implies a causal effect going from corruption indicators to sovereign ratings. Next, the paper briefly describes the sovereign rating methodologies of the three main agencies and shows that they incorporate corruption indicators in their rating criteria. There are, however, differences in the way in which corruption indicators affect the ratings issued by the three agencies. While Fitch has well-defined quantitative criteria for incorporating corruption in its rating opinions, Standard \& Poor's uses a qualitative assessment of the risks arising from corruption, and the criteria used by Moody's lie somewhere in between.

Keywords: corruption, government debt, sovereign ratings

JEL Codes: D73, H63

\footnotetext{
*Author's contact information: Maison de la Paix P1-664, Chemin Rigot 2, Geneva, Switzerland. Email: ugo.panizza@graduateinstitute.ch. The author would like to thank Roberto De Michele, Francesco De Simone, and Carlos Santiso for the invitation to write this paper and for their valuable input, as well as Nicolas Dassen, Federico Galizia, Catherine Greene, Phil Keefer, Yan Liu, Ben Roseth, and Ernesto Stein for their helpful suggestions. This paper was supported by the Inter-American Development Bank Transparency Fund (AAF).
} 


\section{TABLE OF CONTENTS}

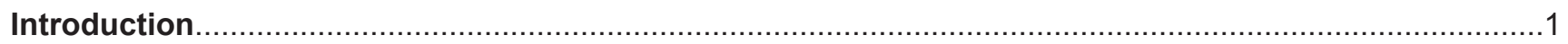

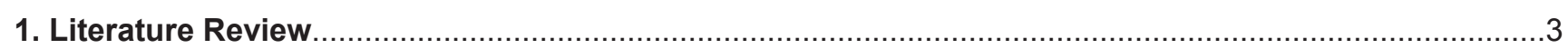

2. The Correlation between Sovereign Rating and Corruption Indicators ..............................................5

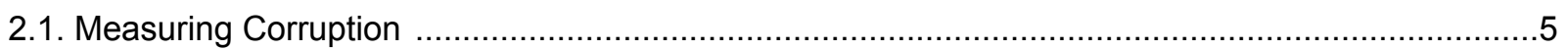

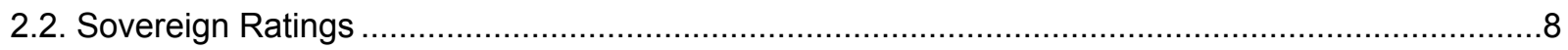

2.3. The Correlation between Corruption Indicators and Sovereign Ratings ...................................10

3. How Sovereign Rating Methodologies Incorporate Corruption Indicators …..................................27

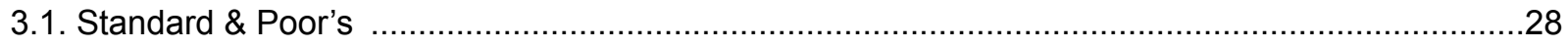

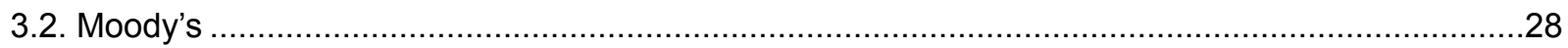

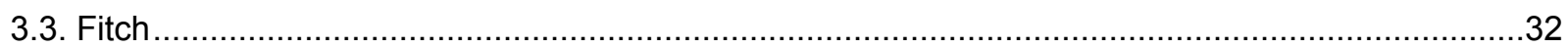

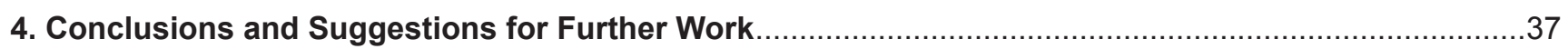

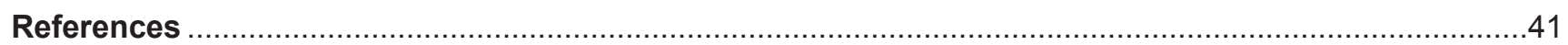

\section{List of Figures}

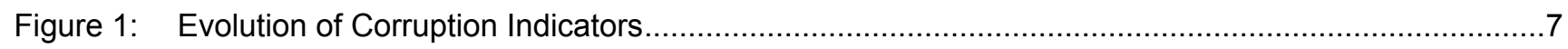

Figure 2: Linear Coding of Credit Rating versus Default Probabilities ......................................................10

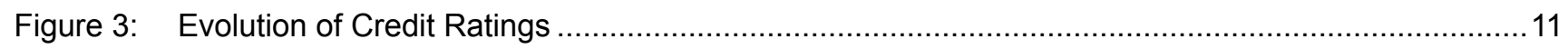

Figure 4: Correlation between Sovereign Rating and ICRG Control of Corruption Indicator (2103 data) .......12

Figure 5: Correlation between Sovereign Rating and WGI Control of Corruption Indicator (2105 data) .........13

Figure 6: Correlation between Sovereign Rating and TI Corruption Perception Index (2105 data).................14

Figure 7: Conditional Correlation between Sovereign Ratings and the ICRG Control of Corruption Indicator .....

Figure 8: Conditional Correlation between Sovereign Ratings and the WGI Control of Corruption Indicator .....

Figure 9: Conditional Correlation between Sovereign Ratings and Tl's Corruption Perception Index

Figure 10: Conditional Correlation between Sovereign Ratings (measured a 1-probability of default) and the ICRG Control of Corruption Indicator.

Figure 11: Conditional Correlation between Sovereign Ratings (measured as 1-probability of default) and the WGI Control of Corruption Indicator

Figure 12: Conditional Correlation between Sovereign Ratings

(measured as 1-probability of default) and TI's Corruption Perception Index

Figure 13: S\&P Sovereign Rating Framework and Aggregation of the Two Profiles ..... .29

Figure 14: Moody's Rating Components and Aggregation Tables .30 


\section{List of Boxes}

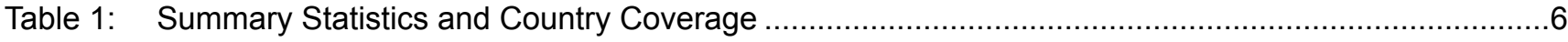

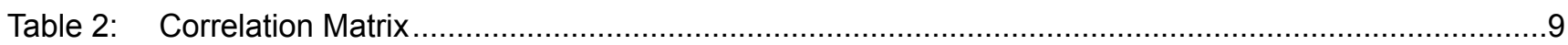

Table 3: Conditional Correlation between Sovereign Ratings and the ICRG Corruption Indicator .................15

Table 4: Conditional Correlation between Sovereign Ratings and the WGI Corruption Indicator ...................16

Table 5: Conditional Correlation between Sovereign Ratings and Transparency International's Control of

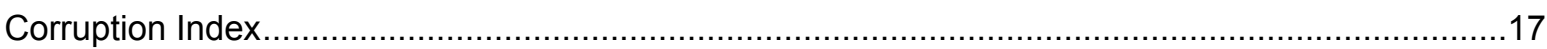

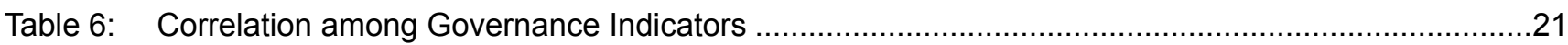

Table 7: Conditional Correlation between Sovereign Ratings and the ICRG Corruption Indicator Controlling for other Governance Indicators

Table 8: Conditional Correlation between Sovereign Ratings and the WGI Corruption Indicator Controllinglfor the Rule of Law WGI Indicator

Table 9: Conditional Correlation between Sovereign Ratings and Corruption Indicators ............................22

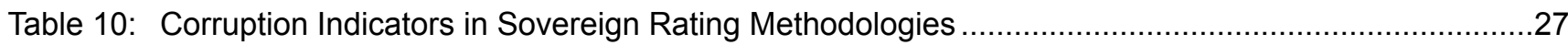

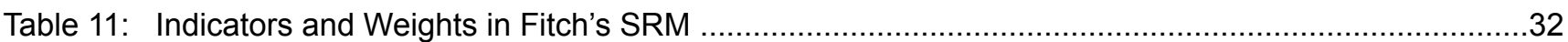

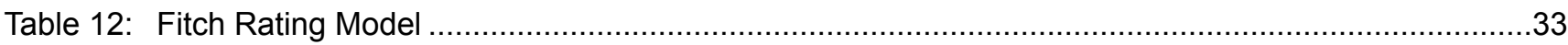





\section{INTRODUCTION}

T his paper presents a detailed analysis of the links between corruption indicators and sovereign ratings. There is a strong correlation between sovereign ratings and each of three widely used corruption indicators. While it is not possible to prove causality, the paper shows that this correlation is robust to controlling for debt and external sustainability, macroeconomic stability, and the overall level of development. However, similar underlying factors drive measures of corruption, bureaucratic quality, investor protection, rule of law, government effectiveness, and democratic accountability. As these different measures of institutional quality are highly correlated with each other, it is difficult to disentangle their individual effects. Hence, the correlation between corruption indicators and sovereign ratings is not always robust to controlling for other measures of institutional quality.

Identifying a causal relationship going from corruption indicators to credit ratings would require an instrumental variable that has a direct effect on corruption but no direct or indirect (except for that going through corruption) impact on rating decisions. In the absence of such an instrument, the paper uses a narrative approach and describes how corruption indicators affect ratings by conducting a detailed analysis of the methodologies of the three main agencies. It shows that while all agencies recognize that corruption is an important indicator for evaluating sovereign creditworthiness, there are important differences in the way that the three agencies incorporate corruption indicators in their methodologies.

The methodology used by Standard \& Poor's is mostly qualitative. The agency states that countries characterized by moderate to high levels of corruption are likely to receive a weak score on the sovereign's institutional assessment, but the methodology does not specify a precise quantitative mapping between any specific corruption indicator and the final score of the institutional assessment.

Moody's uses the control of corruption indicator from the World Bank's Worldwide Governance Indicators (WGI) as part of its institutional strength rating factor. Moody's methodology includes a precise mapping of how the WGI indicators affect the alphanumeric scoring of institutional strength. However, it is impossible to provide a quantitative estimate of how a given change in the control of corruption indicator will affect the final rating because the various rating factors are combined with a nonlinear approach based on a sequence of double entry tables.

Fitch also includes control of corruption in its institutional assessment (which Fitch calls a structural pillar). Fitch provides a quantitative mapping between the WGI and the total score of the structural pillar and uses a linear model to aggregate the four pillars. It is thus possible to simulate how, other things being equal, a change in the corruption indicator affects Fitch sovereign 
ratings. A one-standard-deviation increase in the control of corruption indicator would increase the rating of the median (and average) borrowing member country of the Inter-American Development Bank (IDB) by half a notch.

In summary, there is strong evidence that corruption indicators are closely correlated with sovereign ratings. While the statistical analysis herein cannot prove that lower levels of corruption will lead to higher credit ratings, a detailed analysis of the methodologies of the three main rating agencies suggests that corruption indicators have a causal effect on sovereign ratings. The paper also shows that it is difficult to separate the effect of control of corruption from the overall institutional environment. This makes sense because anti-corruption policies are unlikely to be effective in countries characterized by poor institutions. 


\section{LITERATURE REVIEW}

T his section provides a brief survey of the literature on the drivers of sovereign ratings with particular focus on the scant literature that analyzes the links between corruption and sovereign ratings. It does not attempt to survey the vast literature on the determinants and consequences of corruption. (For a discussion on this topic, see Svensson, 2005.)

Cantor and Packer (1996) were the first to use an econometric model to conduct a systematic analysis of the drivers of the sovereign credit ratings assigned by Standard \& Poor's and Moody's. Their main finding is that a relatively small number of variables explain the ratings assigned by these two agencies. Specifically, they show that eight variables explain more than 90 percent of the cross-country variance of Standard \& Poor's and Moody's sovereign ratings. ${ }^{1}$

Several papers corroborate Cantor and Packer's (1996) findings and add some explanatory variables to their original set of variables. Eichengreen, Hausmann, and Panizza (2003; 2007), for example, analyze the currency composition of external debt. However, most of the recent literature focuses on the cyclical properties of credit ratings and on the possibility that ratings respond asymmetrically to the business cycle (Amato and Furfine, 2004; Bar-Isaac and Shapiro, 2013; Broto and Molina, 2016; Kiff, Kisser, and Schumacher, 2013; Löffler, 2004; and Mora, 2006).

While Moody's (2017a) presents a detailed discussion of the rating implications of the Odebrecht's corruption case, there is no extensive academic literature that specifically focuses on the links between corruption and sovereign ratings. Depken, LaFountain, and Butters (2011) is the only systematic study of the links between corruption and sovereign ratings. ${ }^{2}$ These authors estimate the links between corruption (measured by Transparency International's Corruption Perception Index) and Standard \& Poor's sovereign ratings using an unbalanced panel covering up to 57 countries between 1995 and 2003. Their baseline estimations (based on an ordered probit model that controls for corruption, default history, EU membership, external balance, fiscal balance, GDP growth, inflation, and trade openness) find a large and statistically significant correlation between corruption and credit ratings. Their point estimates suggest that a one-standard-deviation improvement in a country corruption score is associated with a one-notch increase in the sovereign rating. ${ }^{3}$

\footnotetext{
${ }^{1}$ These variables are: per capita income, GDP growth, inflation, fiscal balance, external balance, external debt, an advanced country dummy, and a default history dummy.

2 Depken and LaFountain (2006) focus on the United States and study how state-level corruption affects the rating of bonds issued by the 50 states over the period 1995-2000. Butler and Fauver (2006) use cross-country data to study the links between credit ratings and the overall institutional environment.

${ }^{3}$ The authors also show that a standard linear OLS model yields results which are in line with the ordered probit model.
} 
Depken, LaFountain, and Butters (2011) give a causal interpretation to their results and, by also giving a causal interpretation to the estimated correlation between credit ratings and sovereign spreads, they conclude that a one-standard-deviation reduction in corruption would reduce the interest rate paid by the typical emerging market country by a full percentage point. This effect appears implausibly large, probably because these authors give a causal interpretation to simple correlations. However, when they control for unobserved heterogeneity by augmenting their model with country fixed effects, they no longer find a statistically significant correlation between corruption and credit ratings.

The remainder of the paper builds on the work of Depken, LaFountain, and Butters (2011) and studies the correlation between corruption indicators and sovereign ratings for a larger sample of countries and over a longer period, using three different corruption indicators and sovereign ratings by three different agencies. It will, however, abstain from attaching a causal interpretation to the results. 


\section{THE CORRELATION BETWEEN SOVEREIGN RATING AND CORRUPTION INDICATORS}

$\mathrm{T}$ his section describes the correlation between corruption indicators and sovereign ratings, focusing on three corruption indicators and on the rating of foreign currency long-term debt issued by Standard \& Poor's, Moody's, and Fitch.

\subsection{Measuring Corruption}

Corruption is usually defined as the abuse of entrusted power for private gain. Depending on the amount of money at stake and the sector in which it occurs, it is usually classified as petty, grand, bureaucratic, and political (or institutional) corruption. Petty bureaucratic corruption is often visible on a day-to-day basis because it affects most citizens when they interact with the public administration. Political or institutional corruption is less visible on a day-to-day basis but takes center stage when there are widespread corruption scandals.

For the present study, corruption is measured using three different indicators. The top panel of Table 1 reports summary statistics for the various corruption indicators, and the bottom panel describes their country coverage. ${ }^{4}$

The first indicator is sourced from the International Country Risk Guide (ICRG). The ICRG produces 22 indicators (including measures of government stability, law and order, ethnic tension, democratic accountability, and internal and external conflict), grouped into three subcategories of risk: political, financial, and economic (ICRG also produces a composite risk rating, which is a weighted average of the political, financial, and economic ratings). This paper focuses on the control of corruption indicator, which is available for up to 138 countries starting in 1984 (in 1984, the indicators covered 100 countries). ${ }^{5}$ The ICRG corruption indicator is one of the 12 components of the ICRG political risk indicator. ICRG indicators are based on expert assessments and not on opinion polls or corruption victimization, and the correlation between corruption perception indicators and victimization is far from perfect. ${ }^{6}$

ICRG focuses on political corruption. Its indicator is described as an "assessment of corruption

\footnotetext{
${ }^{4}$ The choice of these three indicators is dictated by their availability for many countries over a period of at least five years.

${ }^{5}$ The dataset covers the period 1984-2013, as data for 2014-17 were not available.

${ }^{6}$ Donchev and Ujhelyi (2014) show that the International Crime Victimization Survey and the World Business Environment Survey are poor predictors of reported corruption perception. Kenny (2009) studies corruption in infrastructure projects and shows that perception measures are weak proxies for the actual extent of grand corruption and are better measures of petty corruption. Razafindrakoto and Roubaud (2010) study eight African countries and find that expert opinions about corruption tend to be biased depending on the political preferences of the experts. Morris (2008) shows that there is a weak correlation between victimization and perception in Mexico, and Olkien (2009) shows the same for Indonesia.
} 
Table 1: Summary Statistics and Country Coverage

\begin{tabular}{lccccc}
\hline & \multicolumn{5}{c}{ Summary statistics } \\
\cline { 2 - 6 } Variable & Obs & Mean & Std. Dev. & Min & Max \\
\hline S\&P & 2,855 & 14.07 & 5.30 & 1 & 21 \\
\hline Moody's & 2,322 & 14.16 & 5.22 & 1 & 21 \\
\hline Fitch & 2,130 & 13.35 & 5.20 & 1 & 21 \\
\hline ICRG & 4,477 & 2.93 & 1.34 & 0 & 6 \\
\hline WGI & 3,477 & -.005 & 1.00 & -2.06 & 2.59 \\
\hline TI & 859 & 42.86 & 19.80 & 8 & 92 \\
\hline & & & Country coverage & & \\
\cline { 2 - 6 } & Period & & Number of countries & Max & \\
\hline S\&P & $1990-2017^{*}$ & 31 & $(1990)$ & 132 & $(2017)$ \\
\hline Moody's & $1990-2017^{*}$ & 27 & $(1990)$ & 109 & $(2017)$ \\
\hline Fitch & $1994-2017$ & 25 & $(1994)$ & 124 & $(2017)$ \\
\hline ICRG & $1990-2013^{* *}$ & 125 & $(1990)$ & 138 & $(2015)$ \\
\hline WGI & $1996-2015$ & 184 & $(1996)$ & 209 & $(2016)$ \\
\hline TI & $2012-2016^{* * *}$ & 172 & $(2012)$ & 176 &
\end{tabular}

Source: Author's elaboration.

Notes: * Data are available from the 1970 s, but this paper uses data starting from $1990 .{ }^{*}$ Data are available from 1984 , but this paper uses data starting in 1990; data also exist for the post-2013 period but are not available. ${ }^{* * *}$ Older data are not comparable.

within the political system" with a special focus on patronage, nepotism, secret party funding, and ties between politics and business. According to ICRG, this type of corruption is particularly risky for foreign investors because it can:

(...) lead to popular discontent, unrealistic and inefficient controls on the state economy, and encourage the development of the black market. The greatest risk in such corruption is that at some time it will become so overweening, or some major scandal will be suddenly revealed, as to provoke a popular backlash, resulting in a fall overthrow of the government, a major reorganizing or restructuring of the country's political institutions, or, at worst, a breakdown in law and order, rendering the country ungovernable (PRS Group, undated: 5).

The indicator ranges between 0 (maximum amount of corruption) and 6 (minimum amount of corruption). The mean value is 3 , with a standard deviation of 1.3 (Table 1). ${ }^{7}$ There are two ways to look at the dispersion of the corruption indicator. First, it is possible to study the amount that corruption can change inside a given country (this is the within-country standard deviation). Second, one could look at the variation of corruption across countries (this is the cross-country standard deviation). In the ICRG data, the crosscountry standard deviation (1.2) is much larger than the within-country standard deviation (0.8).

\footnotetext{
${ }^{7}$ As annual averages of monthly data are used, the values are not necessarily integers.
} 

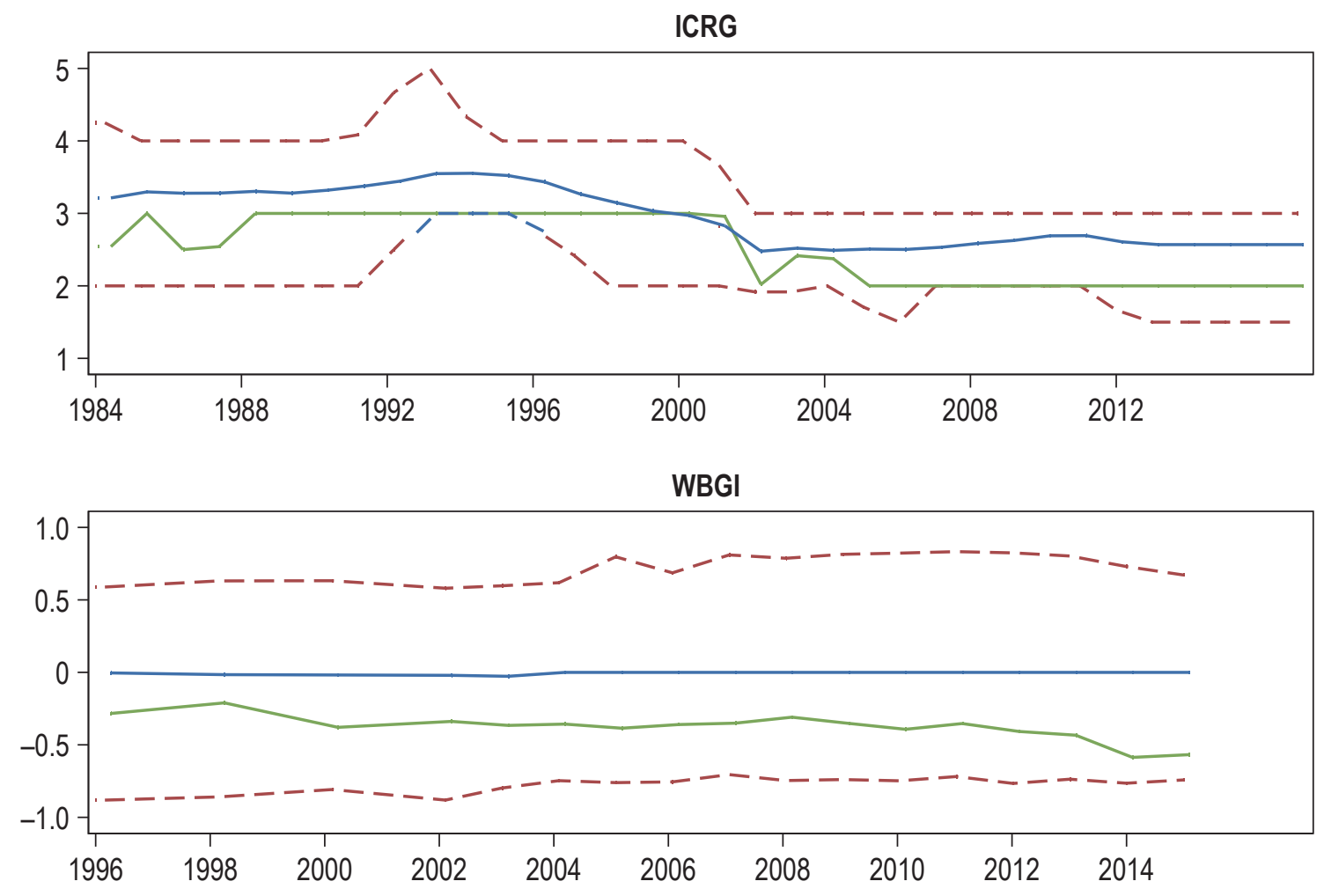

Source: Author's elaboration based on ICRG and World Bank data.

Notes: The solid blue line plots the cross-country average of the indicator and the dotted lines plot the interquartile range. The solid green line plots the median value for the 26 IDB borrowing countries.

For normally distributed variables, the probability of observing a change greater than two standard deviations is very low ( 2.5 percent); thus, it is unlikely that a country can improve its corruption score by more than 1.6 points.

The average corruption score increased from 3.2 in 1984 to a maximum of approximately 3.5 in the mid-1990s and then started decreasing again, bottoming out at 2.5 in 2004 (top panel of Figure 1)..$^{8}$ The median IDB borrowing country has a lower ICRG control of corruption score than the cross-country average. Since 2001, the median control of corruption scores of IDB borrowing countries has deteriorated more rapidly than that of the average country, and the median value for the Latin American and Caribbean (LAC) region is now close to the 25th percentile of the worldwide distribution of this indicator. In 2013, there were only three IDB borrowing countries with a score above 2.5.9

The second measure of corruption is sourced from the WGI. The World Bank's Worldwide Governance Indicators (WGI) consists of six aggregate governance indicators (control of corruption, government effectiveness, rule of law, regulatory quality, political stability, and voice and accountability) obtained by aggregating the views of enterprises, citizens, and experts in

\footnotetext{
${ }^{8}$ Note that this decrease in the average score is not due to the changing sample (the panel includes more countries in 2013 than in the mid1990s). The same pattern is obtains from a balanced panel covering the 100 countries for which data are available starting in 1984.

9 These countries were: Bahamas (4), Uruguay (4), and Chile (4.5).
} 
advanced and developing economies. Specifically, the WGI uses an unobserved components model to construct a weighted average of more than 30 individual data sources produced by international organizations, nongovernmental organizations (NGOs), think tanks, and private sector firms (for a description of the methodology, see Kaufmann, Kraay, and Mastruzzi, 2011)..$^{10}$ The indicators cover up to 211 countries for the years 1996, 1998, and 2000, and the annual WGI is available for the years 2002 to 2015. The WGI control of corruption indicator ranges between -2 and 2.5 and is normalized to have constant mean (zero) and standard deviation (one). Because of this normalization, there is no trend in the behavior of the average WGI corruption indicator (bottom panel of Figure 1).

The WGI control of corruption indicator for the median IDB borrowing country is well below the cross-country average, and the distance between the median IDB borrowing country and the cross-country average has increased in the last decade, placing the median IDB borrowing country close to the bottom 25th percentile of the worldwide distribution of the index. In 2015, there were only five IDB borrowing countries with a positive (i.e., above the cross-country average) control of corruption score and only four countries with a score greater than $1 .{ }^{11}$

Finally, the paper analyzes the behavior of the Corruption Perceptions Index compiled by Transparency International ( $\mathrm{TI}$ ). TI also measures corruption by aggregating a large number of indicators. Specifically, the aggregate Corruption Perceptions Index is built by averaging (after standardization) 13 data sources (from 12 institutions) that measure perceptions of corruption within the previous two years. ${ }^{12}$ While data have been collected since 1995, the collection methodology changed in $2012 .{ }^{13}$ Therefore, only data for the 2012-16 period are considered. The index can potentially range between 0 (maximum level of corruption) and 100 , but the actual range in my data (which cover up to 175 countries) is $8-92$ (Table 1 ). In the period 2012-16, the average value remained constant at around 43, with a standard deviation of 20 .

The three corruption indices are highly correlated with each other. The correlation between ICRG and WGI is 86 percent, that between ICRG and $\mathrm{TI}$ is 95 percent, and the correlation between WGI and TI is 99 percent (Table 2). The ICRG index is one of the contributors of both WGI and TI corruption data.

\subsection{Sovereign Ratings}

In studying the correlation between corruption and ratings, this subsection focuses on the long-term foreign currency ratings issued by Standard \& Poor's, Moody's, and Fitch. While rating agencies also issue short-term and local currency ratings, the focus on long-term foreign currency ratings is justified by the fact these ratings are the baseline for the overall rating scale of countries that issue both domestic and foreign currency debt. ${ }^{14}$

\footnotetext{
${ }^{10}$ A full list of sources is available at http://info.worldbank.org/governance/wgi/index.aspx\#doc.

${ }_{11}$ The countries are: Costa Rica (0.7), Chile (1.28), Bahamas (1.29), Uruguay (1.30), and Barbados (1.79).

12 The list of sources is available at https://www.transparency.org/news/feature/corruption_perceptions_index_2016\#resources

${ }^{13}$ Transparency International (2012: 1) clarifies that before 2012, CPI scores were not comparable over time and explains that "Previously, the CPI was based on perceptions of corruption in each country/territory, relative to the other countries scored and ranked on this index. This was because the Index captured the rank position of each country in each data source, so that country scores were highly dependent on the changes in scores of the countries around it in the index. Starting in 2012, we will be using the raw scores from each of the data sources, which provide greater transparency as to how the CPI scores have been constructed and better enable capturing changes over time."

14 There is often an upward adjustment for local currency ratings. This adjustment is normally justified by the fact that local currency debt can be backed by the national central bank or more easily placed in the domestic banking system.
} 
Table 2: Correlation Matrix

\begin{tabular}{lllllll}
\hline & S\&P & Moody's & Fitch & ICRG & WGI & TI \\
\hline S\&P & 1.0000 & & & & & \\
\hline Moody's & $0.97^{* * *}$ & 1.00 & & & & \\
\hline Fitch & $0.99^{* * *}$ & $0.97^{* * *}$ & 1.00 & & & \\
\hline ICRG & $0.74^{* * *}$ & $0.70^{* * *}$ & $0.75^{* * *}$ & 1.00 & & \\
\hline WGI & $0.82^{* * *}$ & $0.81^{* * *}$ & $0.83^{* * *}$ & $0.86^{* * *}$ & 1.00 & \\
\hline TI & $0.78^{* * *}$ & $0.76^{* * *}$ & $0.81^{* * *}$ & $0.95^{* * *}$ & $0.99^{* * *}$ & 1.00 \\
\hline
\end{tabular}

Source: Author's elaboration.

Notes: ${ }^{* * *}$ indicates that the correlation is statistically significant at the $1 \%$ confidence level.

The three main rating agencies do not express their rating opinions with numerical scores. Ratings are instead communicated with alphanumeric scores that range between AAA (the highest rating) and D/SD (meaning that a country is in default) for Standard \& Poor's and Fitch and between Aaa and C for Moody's. To study the correlation between sovereign ratings and corruption indicators, a numerical score is assigned to each rating category, starting with 21 for the highest rating (AAA for Standard \& Poor's and Fitch and Aaa for Moody's) and 1 for the lowest rating category (D/SD, and $\mathrm{C}$ respectively).

An alternative method to transform ratings into numerical variables that can be used to conduct a formal statistical analysis is to assign them values that map the historical probability of default associated with a specific rating. Given that sovereign defaults are rare events, these default probabilities are normally calculated using corporate bond default rates. For Standard \& Poor's and Fitch ratings (the two agencies using the same scale), ratings with the five-year global corporate average cumulative default rates are mapped (Standard and Poor's, 2017) and then the cumulative default rate are rescaled to range between 0 and 1 and the ratings coded as 1-probability of default. A score of 1 denotes an issuer with zero likelihood of default (AAA rating), and a score of 0 denotes an issuer in default (SD rating). For Moody's ratings, the CDO weighted average rating factor (Moody's, 2017b) is used and then the variables rescaled so that 1 indicates no risk of default and 0 indicates an issuer in default.

Mapping ratings into default probabilities yields a nonlinear relationship between ratings and the score. Default probabilities decrease very rapidly in the CCC to BBB+ range and then flatten when countries reach high-grade ratings (see Figure 2). The empirical analysis below focuses on the linear scores, but it also shows what happens when rating categories are scored with default probabilities.

Sovereign ratings issued by the three agencies are closely correlated with each other, and the correlation coefficients range between 97 and 99 percent (Table 2). The average rating in the sample is about 13-14 (Table 1). This is just above the investment grade category and in the BBB range for Standard \& Poor's and Fitch and in the Baa range in the Moody's classification. Average credit ratings were higher at the beginning of the sample (in the $A A$ to $A$ range) and decreased rapidly in the 1990s (Figure 3). This decrease in rating is not due to a generalized decrease in credit quality, but to the fact that the universe of rated sovereigns increased substantially over the last 20 years (in 1990, Standard \& Poor's and Moody's rated 
Figure 2. Linear Coding of Credit Rating versus Default Probabilities
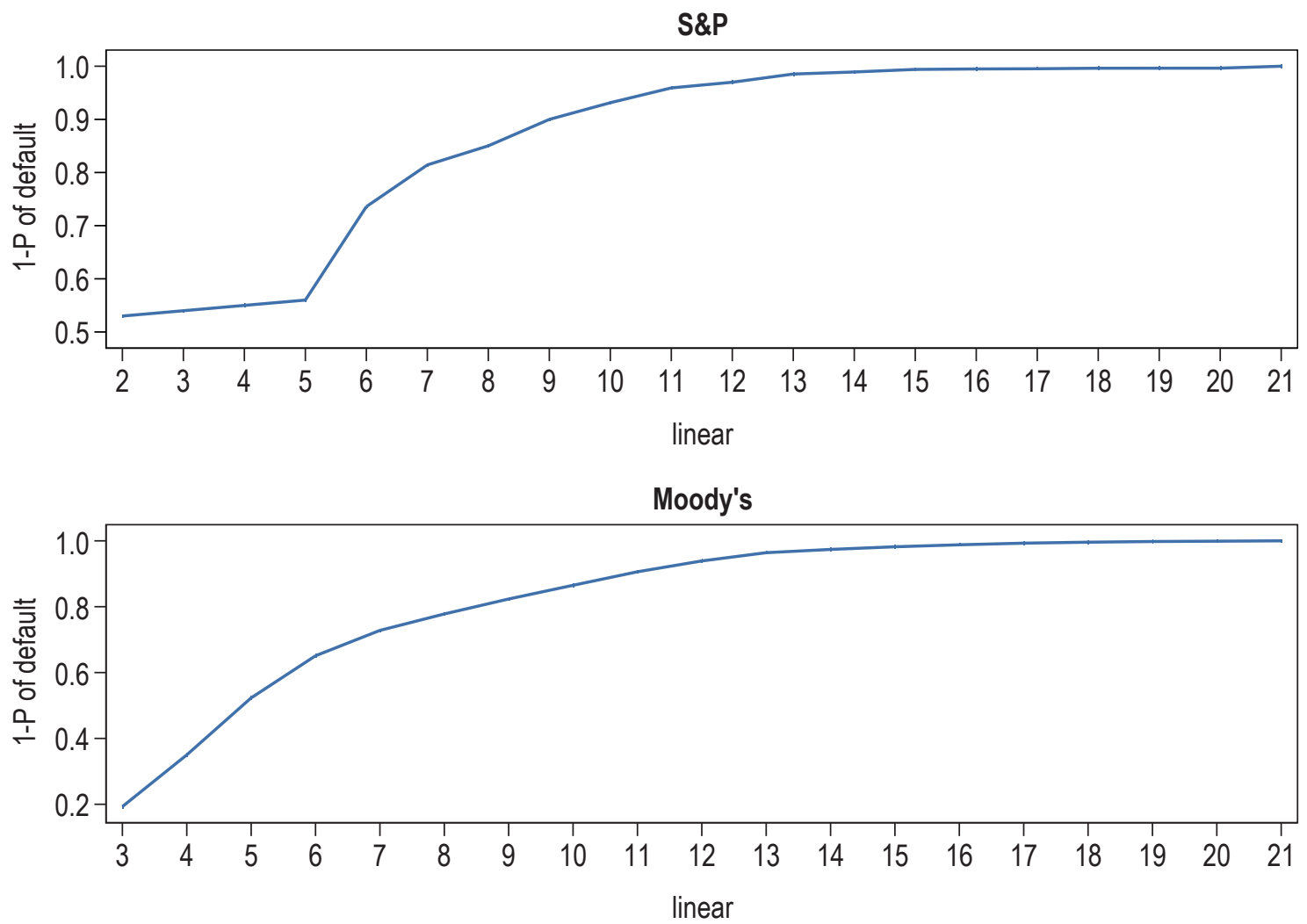

Source: Author's elaboration based on Moody's and Standard \& Poor's data.

Note: The horizontal axis plots credit ratings coded linearly (1=SD; $21=A A A$ with each notch being a one-point increment) and the vertical axis maps ratings into 1-empirical default probability.

approximately 30 sovereigns, these two agencies now rate more than 100 sovereigns each). Most of the newly rated sovereigns are developing countries, which tend to have lower ratings than the advanced economies, which were already receiving a credit rating in the early 1990s.

The bottom right panel of Figure 3 plots average ratings for the three main agencies using a constant sample of countries (all countries that had a rating in 2000). ${ }^{15}$ The figure shows that average ratings were improving until 2007/2008 and then started deteriorating in the aftermath of the global financial crisis.

\subsection{The Correlation between Corruption Indicators and Sovereign Ratings}

Credit ratings are strongly correlated with corruption indicators: correlation coefficients range between 70 percent (Moody's and ICRG index)

${ }^{15}$ The sample includes 86 countries rated by Standard and Poor's, 87 countries rated by Moody's, and 69 countries rated by Fitch. 
Figure 3. Evolution of Credit Ratings
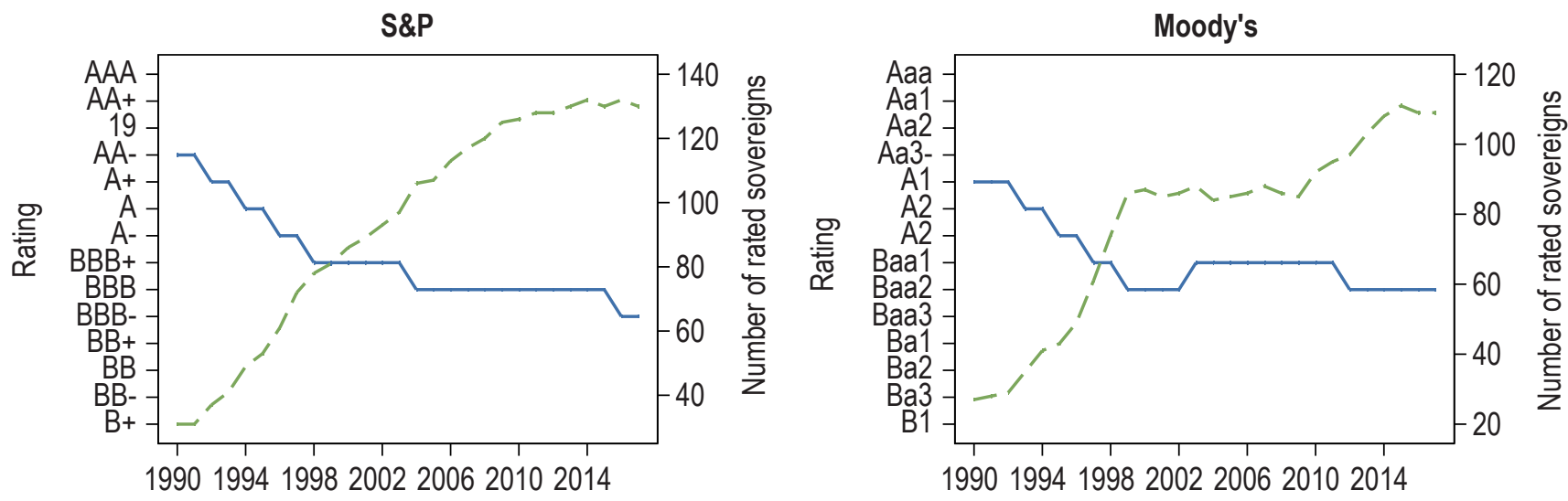

Fitch
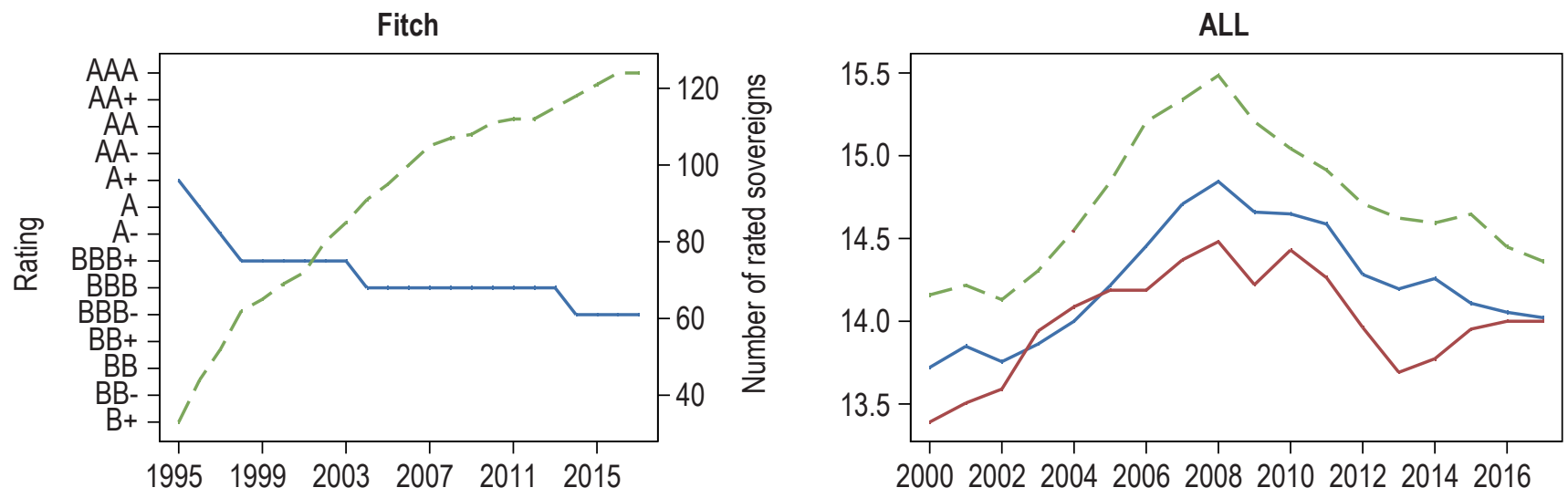

Source: Author's elaboration based on data from Fitch, Moody's, and Standard \& Poor's.

Notes: In the first three graphs, the solid line plots the average rating and the dashed line is the number of rated sovereigns (right axis). The last graph plots average credit ratings focusing on a constant sample of countries for which there was a rating in the year 2000. The solid blue line plots the average Standard \& Poor's rating, the solid red line plots the average Moody's rating and the dashed green line plots the average Fitch rating.

and 83 percent (Fitch and the WGI index). Figures 4 to 6 illustrate this correlation using crosscountry data for 2015 (2013 in the case of the ICRG index). Each point in the scatter plots represents one country (IDB borrowing countries are also labeled with their three-letter ISO code) and each scatter plot is divided into six quadrants: the upper right-quadrant denotes countries which have prime or high grade rating (i.e., a credit rating of at least AA- or Aa3) and low levels of corruption (defined as being in the top 25th percentile of the distribution of the indicator), the middle-right quadrant denotes low corruption countries with a credit rating above investment grade (the investment grade line is the dashed horizontal line) but below high grade, and the lower-right quadrant denotes countries with low corruption and noninvestment grade rating. The left-hand side quadrants are similar to the right-hand side quadrants but only contain countries with corruption scores in the bottom 75 percent of the distribution.

The upper-left quadrants are either empty or only include China and a couple of high-income oil exporters (Kuwait and Saudi Arabia). There are thus no "normal" (medium sized countries which are not oil exporters) countries with high or moderate rates of corruption and prime or high-grade rating. The bottom-right quadrant (low corruption and below investment grade credit rating) is also scarcely populated. Countries in this quadrant tend to be high-income or 
Figure 4. Correlation between Sovereign Rating and ICRG Control of Corruption Indicator (2103 data)
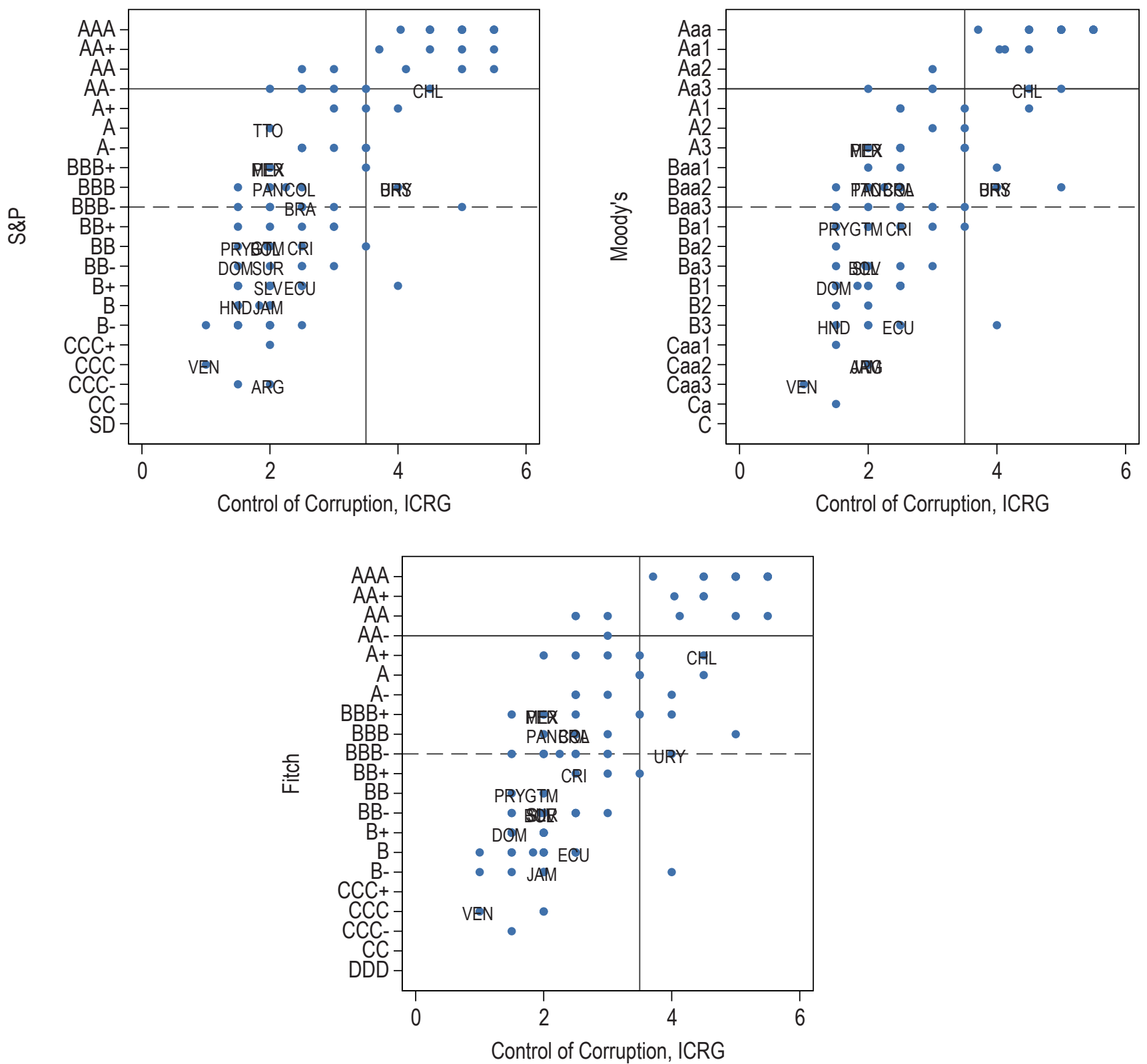

Source: Author's elaboration based on Fitch, Moody's, Standard \& Poors and ICRG data.

upper-middle-income countries with high levels of debt, such as Barbados and Cyprus. Most countries belong either in the bottom-left quadrant (low rating/high corruption) or the top right quadrant (high rating/low corruption), confirming the positive correlation between sovereign rating and control of corruption. Most IDB borrowing countries which have an investment-grade rating (but not a high-grade rating) are in the bottom 75 percent of the distribution of the control of corruption indicators (the exceptions are Chile and Uruguay).

To further explore the correlation between sovereign ratings and corruption indicators, a set of cross-country regressions are estimated in which the dependent variable is the average credit rating of a given country over a certain 
Figure 5. Correlation between Sovereign Rating and WGI Control of Corruption Indicator (2105 data)
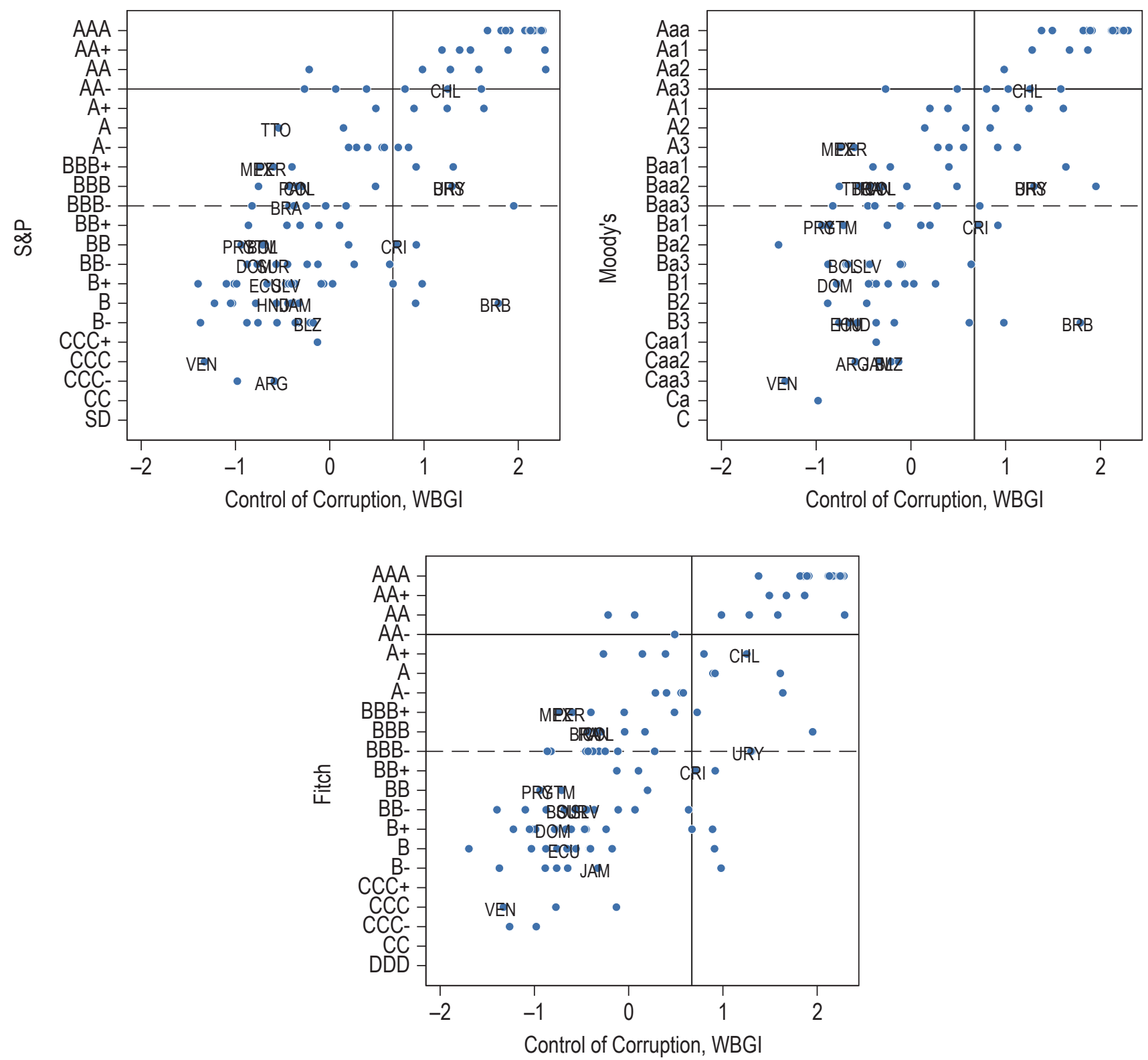

Source: Author's elaboration based on Fitch, Moody's, Standard \& Poors and World Bank data.

number of years, and the explanatory variables are the period average of the corruption indicator, a measure of economic development (the log of GDP per capita in PPP dollars), an indicator of fiscal sustainability (the public debtto-GDP ratio), an indicator of external sustainability (the current account-to-GDP ratio), and an indicator of macroeconomic stability (log inflation).
The corruption coefficients in these regressions should be interpreted as the correlation between corruption and credit ratings conditional on all other variables included in the statistical model. They measure the correlation between corruption and credit ratings while recognizing that countries characterized by high levels of corruption are also likely to have lower GDP per capita, larger current account deficits, higher debt, and 
Figure 6. Correlation between Sovereign Rating and TI Corruption Perception Index (2105 data)
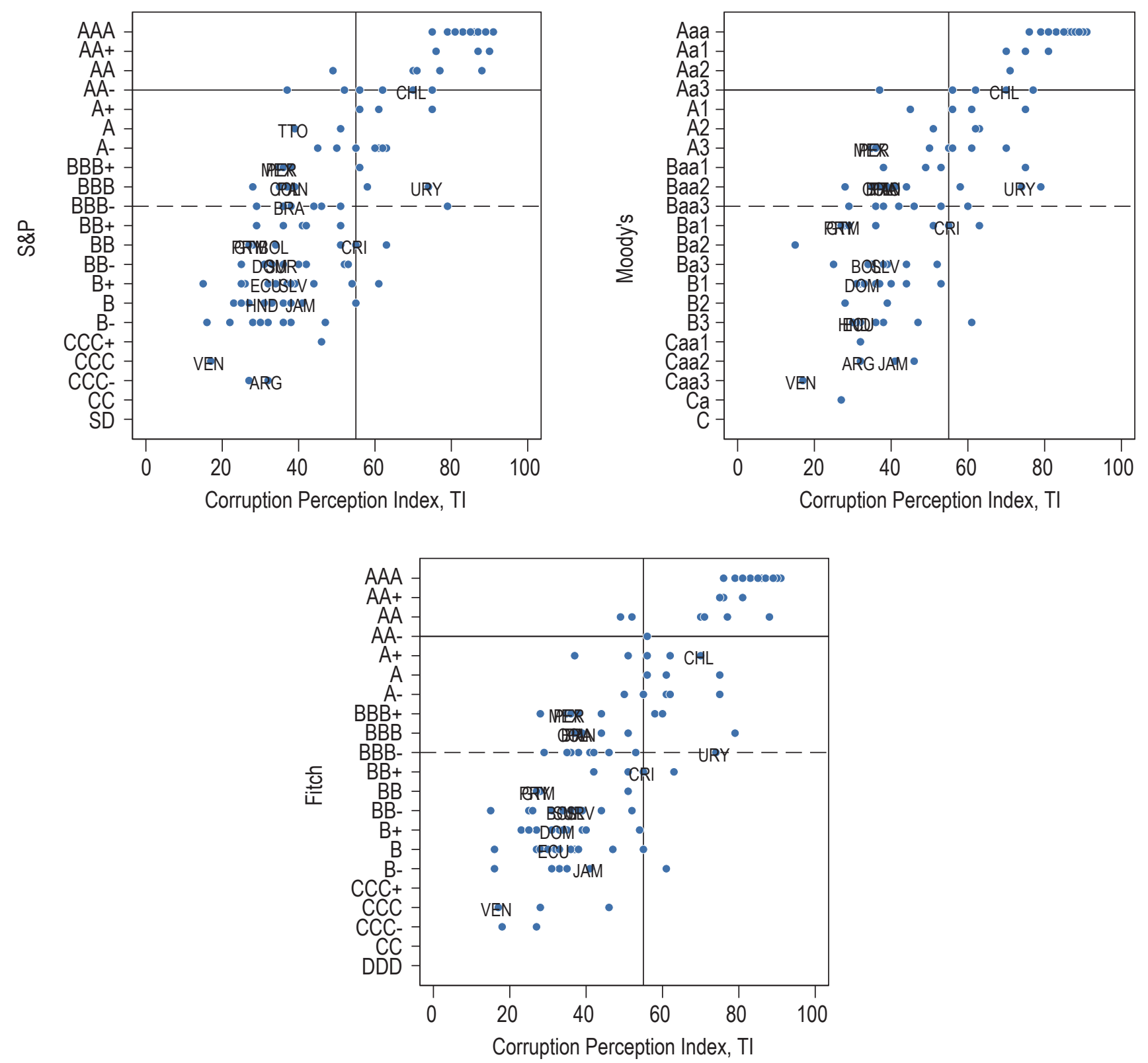

Source: Author's elaboration based on Fitch, Moody's, Standard \& Poors and TI data.

higher inflation. Simple correlations that do not condition these other factors may overestimate the correlation between corruption and credit rating by wrongly attributing to corruption the effect of GDP per capita, external and fiscal sustainability, or macroeconomic instability.

The focus is on period averages to abstract from business cycle considerations and because not much can be learned from the year-over-year variations of slow-moving variables such as corruption indicators. Specifically, the focus is on the 1990s (the ICRG Index is available starting in 1984, but only a handful of countries were rated in the 1980s), the pre-global financial crisis period (2000-07), and the post global financial crisis period (2008-15). 
As expected, ratings are positively correlated with the level of development and with current account surpluses and they are negative correlated with the level of debt and inflation (Tables 3-5). The positive correlation between credit ratings and control of corruption is robust to controlling for the level of development, macro stability, and fiscal and external sustainability. The coefficients of the control of corruption indicators are always positive and statistically significant at the one percent level. Note that this parsimonious set of control variables explain more than 80 percent of the variance of credit ratings by most agencies in most period (the regressions' $\mathrm{R} 2$ range between 0.73 and 0.86 ).

Note that the estimated effects are quantitatively large. Consider, for instance, the point estimates of Table 4. The coefficients attached to the control of corruption variable indicate that a onestandard-deviation improvement in the indicator is associated with approximately a 2.5 notch increase in credit rating. This is much larger that the effect associated with a one-standard- deviation improvement in the other control variables. For instance, a one-standard-deviation reduction in the debt-to-GDP ratio is associated with a half a notch increase in rating, a one-standard-deviation improvement in the current account balance is associated with a 0.2 notch rating increase and a one-standard-deviation reduction in inflation is associated with a 0.75 notch increase in rating.

The regressions of Tables $3-5$ show that there is a strong conditional correlation (i.e., a that recognizes that both corruption and credit ratings are also correlated with the other variables included in the regression model) between corruption and credit ratings. However, this correlation does not prove that corruption indicators cause rating opinions. While reverse causality (i.e., the possibility that ratings cause

Table 3: Conditional Correlation between Sovereign Ratings and the ICRG Corruption Indicator

\begin{tabular}{|c|c|c|c|c|c|c|c|c|c|}
\hline & (1) & (2) & (3) & (4) & (5) & (6) & (7) & (8) & (9) \\
\hline Corr (ICRG) & $\begin{array}{l}1.207^{\star * *} \\
(0.301)\end{array}$ & $\begin{array}{l}1.477^{\star * *} \\
(0.273)\end{array}$ & $\begin{array}{c}0.966^{* * *} \\
(0.354)\end{array}$ & $\begin{array}{l}1.773^{\star * *} \\
(0.244)\end{array}$ & $\begin{array}{l}1.523^{\star \star *} \\
(0.279)\end{array}$ & $\begin{array}{l}1.737^{\star * *} \\
(0.260)\end{array}$ & $\begin{array}{l}2.000^{* * *} \\
(0.233)\end{array}$ & $\begin{array}{l}1.908^{\star \star \star} \\
(0.272)\end{array}$ & $\begin{array}{l}1.990^{\star \star \star} \\
(0.239)\end{array}$ \\
\hline $\ln (G D P P C)$ & $\begin{array}{c}2.209^{* \star *} \\
(0.439)\end{array}$ & $\begin{array}{l}1.524^{\star \star *} \\
(0.448)\end{array}$ & $\begin{array}{l}2.322^{\star * *} \\
(0.566)\end{array}$ & $\begin{array}{l}2.279^{\star * *} \\
(0.299)\end{array}$ & $\begin{array}{l}2.781^{\star \star *} \\
(0.404)\end{array}$ & $\begin{array}{l}2.138^{* * *} \\
(0.327)\end{array}$ & $\begin{array}{l}1.666^{* * \star} \\
(0.291)\end{array}$ & $\begin{array}{l}1.857^{\star * *} \\
(0.392)\end{array}$ & $\begin{array}{l}1.772^{\star \star \star} \\
(0.314)\end{array}$ \\
\hline Debt-to-GDP & $\begin{array}{c}-1.030 \\
(1.017)\end{array}$ & $\begin{array}{c}-0.018 \\
(0.989)\end{array}$ & $\begin{array}{c}0.187 \\
(1.104)\end{array}$ & $\begin{array}{c}-1.060 \\
(0.750)\end{array}$ & $\begin{array}{c}-1.777^{\star *} \\
(0.797)\end{array}$ & $\begin{array}{c}-1.006 \\
(0.753)\end{array}$ & $\begin{array}{c}-1.771^{* * *} \\
(0.673)\end{array}$ & $\begin{array}{c}-2.305^{* * *} \\
(0.753)\end{array}$ & $\begin{array}{c}-1.606^{\star *} \\
(0.678)\end{array}$ \\
\hline CA-to-GDP & $\begin{array}{l}19.408^{\star * *} \\
(6.887)\end{array}$ & $\begin{array}{l}17.239^{* * *} \\
(6.132)\end{array}$ & $\begin{array}{l}13.139^{*} \\
(7.652)\end{array}$ & $\begin{array}{c}-1.173 \\
(3.325)\end{array}$ & $\begin{array}{r}-7.062^{*} \\
(3.551)\end{array}$ & $\begin{array}{c}-2.064 \\
(3.563)\end{array}$ & $\begin{array}{l}10.444^{* * *} \\
(3.603)\end{array}$ & $\begin{array}{c}6.271 \\
(4.049)\end{array}$ & $\begin{array}{c}7.810^{\star *} \\
(3.814)\end{array}$ \\
\hline $\ln ($ infl) & $\begin{array}{c}-1.350^{* * *} \\
(0.262)\end{array}$ & $\begin{array}{c}-0.923^{* * *} \\
(0.252)\end{array}$ & $\begin{array}{c}-1.020^{* * *} \\
(0.264)\end{array}$ & $\begin{array}{c}-1.614^{* * *} \\
(0.284)\end{array}$ & $\begin{array}{c}-1.838^{* * *} \\
(0.357)\end{array}$ & $\begin{array}{c}-1.723^{* * *} \\
(0.314)\end{array}$ & $\begin{array}{c}-0.878^{* * *} \\
(0.274)\end{array}$ & $\begin{array}{c}-1.123^{* * *} \\
(0.321)\end{array}$ & $\begin{array}{l}-0.943^{* * \star} \\
(0.283)\end{array}$ \\
\hline Constant & $\begin{array}{r}-7.602^{*} \\
(3.975) \\
\end{array}$ & $\begin{array}{c}-3.627 \\
(4.237) \\
\end{array}$ & $\begin{array}{r}-8.672^{*} \\
(4.915) \\
\end{array}$ & $\begin{array}{c}-10.774^{* * *} \\
(2.680) \\
\end{array}$ & $\begin{array}{c}-14.251^{* * *} \\
(3.750) \\
\end{array}$ & $\begin{array}{c}-9.063^{* * *} \\
(2.968) \\
\end{array}$ & $\begin{array}{c}-6.936^{* *} \\
(2.694) \\
\end{array}$ & $\begin{array}{c}-7.948^{* *} \\
(3.674) \\
\end{array}$ & $\begin{array}{c}-7.957^{\star \star \star} \\
(2.935) \\
\end{array}$ \\
\hline Observations & 63 & 65 & 49 & 97 & 86 & 92 & 109 & 99 & 106 \\
\hline R-squared & 0.799 & 0.768 & 0.795 & 0.837 & 0.821 & 0.838 & 0.832 & 0.796 & 0.833 \\
\hline Rating agency & S\&P & Moody's & Fitch & S\&P & Moody's & Fitch & S\&P & Moody's & Fitch \\
\hline Period & 1990s & 1990s & 1990s & 2000-07 & $2000-07$ & 2000-07 & 2008-13 & 2008-13 & 2008-13 \\
\hline
\end{tabular}

Source: Author's elaboration

Notes: * statistically significant at the $10 \%$ confidence level, ${ }^{* *}$ statistically significant at the $5 \%$ confidence level, and ${ }^{* * *}$ statistically significant at the $1 \%$ confidence level. 
Table 4: Conditional Correlation between Sovereign Ratings and the WGI Corruption Indicator

\begin{tabular}{|c|c|c|c|c|c|c|c|c|c|}
\hline & (1) & (2) & (3) & (4) & (5) & (6) & (7) & (8) & (9) \\
\hline Corr (WGI) & $\begin{array}{l}2.250^{* * *} \\
(0.430)\end{array}$ & $\begin{array}{l}2.749^{* * *} \\
(0.404)\end{array}$ & $\begin{array}{l}2.267^{\star * \star} \\
(0.405)\end{array}$ & $\begin{array}{l}2.924^{* * *} \\
(0.306)\end{array}$ & $\begin{array}{l}2.722^{* * *} \\
(0.374)\end{array}$ & $\begin{array}{l}2.775^{\star * *} \\
(0.300)\end{array}$ & $\begin{array}{l}2.504^{* * *} \\
(0.299)\end{array}$ & $\begin{array}{l}2.592^{* * *} \\
(0.361)\end{array}$ & $\begin{array}{l}2.604^{* \star *} \\
(0.292)\end{array}$ \\
\hline $\ln (G D P P C)$ & $\begin{array}{l}1.465^{\star * *} \\
(0.469)\end{array}$ & $\begin{array}{c}0.495 \\
(0.464)\end{array}$ & $\begin{array}{c}1.353^{\star *} \\
(0.510)\end{array}$ & $\begin{array}{c}1.349^{* * *} \\
(0.303)\end{array}$ & $\begin{array}{l}1.794^{* * *} \\
(0.452)\end{array}$ & $\begin{array}{l}1.533^{* * *} \\
(0.295)\end{array}$ & $\begin{array}{c}1.139^{* * *} \\
(0.318)\end{array}$ & $\begin{array}{l}1.264^{* * *} \\
(0.440)\end{array}$ & $\begin{array}{l}1.154^{* * *} \\
(0.312)\end{array}$ \\
\hline Debt-to-GDP & $\begin{array}{c}-0.927 \\
(0.944)\end{array}$ & $\begin{array}{l}-0.287 \\
(1.000)\end{array}$ & $\begin{array}{c}0.001 \\
(0.912)\end{array}$ & $\begin{array}{c}-1.668^{* *} \\
(0.646)\end{array}$ & $\begin{array}{c}-1.549^{* *} \\
(0.734)\end{array}$ & $\begin{array}{c}-1.020 \\
(0.657)\end{array}$ & $\begin{array}{c}-1.949^{* * *} \\
(0.687)\end{array}$ & $\begin{array}{c}-2.148^{* * *} \\
(0.761)\end{array}$ & $\begin{array}{c}-1.388^{* *} \\
(0.667)\end{array}$ \\
\hline CA-to-GDP & $\begin{array}{l}17.549^{* \star \star} \\
(6.428)\end{array}$ & $\begin{array}{c}4.526 \\
(5.745) \\
\end{array}$ & $\begin{array}{c}12.875^{\star *} \\
(6.323) \\
\end{array}$ & $\begin{array}{c}3.581 \\
(2.763) \\
\end{array}$ & $\begin{array}{c}-4.267 \\
(3.175) \\
\end{array}$ & $\begin{array}{c}-1.279 \\
(3.001) \\
\end{array}$ & $\begin{array}{l}17.778^{* * \star} \\
(3.338)\end{array}$ & $\begin{array}{l}12.751^{\star * *} \\
(3.704)\end{array}$ & $\begin{array}{l}13.961^{* * *} \\
(3.593)\end{array}$ \\
\hline $\ln (\mathrm{infl})$ & $\begin{array}{c}-0.876^{* * *} \\
(0.270)\end{array}$ & $\begin{array}{c}-0.628^{* *} \\
(0.258)\end{array}$ & $\begin{array}{l}-0.554^{* *} \\
(0.221)\end{array}$ & $\begin{array}{c}-0.983^{* * *} \\
(0.265)\end{array}$ & $\begin{array}{c}-1.132^{* * *} \\
(0.347)\end{array}$ & $\begin{array}{c}-1.148^{* * *} \\
(0.274)\end{array}$ & $\begin{array}{l}-0.727^{* * *} \\
(0.275)\end{array}$ & $\begin{array}{c}-0.760^{* *} \\
(0.324)\end{array}$ & $\begin{array}{l}-0.824^{* * *} \\
(0.277)\end{array}$ \\
\hline Constant & $\begin{array}{c}1.618 \\
(4.294) \\
\end{array}$ & $\begin{array}{c}9.294^{* *} \\
(4.413) \\
\end{array}$ & $\begin{array}{c}1.846 \\
(4.690) \\
\end{array}$ & $\begin{array}{c}1.373 \\
(2.811) \\
\end{array}$ & $\begin{array}{c}-2.660 \\
(4.288) \\
\end{array}$ & $\begin{array}{c}-0.197 \\
(2.826) \\
\end{array}$ & $\begin{array}{c}3.075 \\
(3.045) \\
\end{array}$ & $\begin{array}{c}2.009 \\
(4.309) \\
\end{array}$ & $\begin{array}{c}2.799 \\
(3.018) \\
\end{array}$ \\
\hline Observations & 64 & 69 & 51 & 108 & 91 & 100 & 123 & 108 & 115 \\
\hline R-squared & 0.824 & 0.748 & 0.861 & 0.853 & 0.838 & 0.870 & 0.816 & 0.784 & 0.832 \\
\hline Rating agency & S\&P & Moody's & Fitch & S\&P & Moody's & Fitch & S\&P & Moody's & Fitch \\
\hline Period & 1990s & 1990s & 1990s & 2000-07 & 2000-07 & 2000-07 & 2008-15 & 2008-15 & 2008-15 \\
\hline
\end{tabular}

Source: Author's elaboration based on Fitch, Moody's, Standard \& Poors, and World Bank data.

Notes: * statistically significant at the $10 \%$ confidence level, ${ }^{* *}$ statistically significant at the $5 \%$ confidence level, and ${ }^{* *}$ statistically significant at the $1 \%$ confidence level.

corruption) is not a particular concern, there are several unobservable country characteristics that are likely to be jointly correlated with corruption indicators and sovereign ratings. It is impossible to exclude that these unobservable country characteristics are the drivers of the observed correlation between credit ratings and corruption indicators. While it is impossible to quantify the effect of these unobservable country characteristics, it is likely that they are positively correlated with both control of corruption and credit ratings. In this case, a standard result in econometrics indicates that the regressions of Tables 3-5 are overestimating the link between corruption and sovereign ratings. The true correlation between corruption and credit rating is thus likely to be lower than what the results of Tables $3-5$ suggest.
Figures 7-9 plot the conditional correlation between credit ratings and corruption indicators. ${ }^{16}$ These are partial average plots that do not show the original credit ratings and corruption indicators. They show the values of credit ratings and corruption conditional on all other independent variables included in the regressions. The graphs show the regression line and a scatter plot where each country is a dot and the IDB borrowing countries are labeled with their three-letter ISO code.

The figures show an interesting pattern. In earlier periods (the 1990s and 2000-07), most IDB borrowing countries were below the regressions line (the exceptions are Chile, Colombia, and El Salvador) suggesting that these countries had credit ratings which were lower (conditional on

\footnotetext{
${ }^{16}$ There are 21 panels in total. Each panel plots the conditional correlation between one of the corruption indicators described above and the numerical credit rating score of one of the three rating agencies. In Figures 7 and 8, each row represents one of the three periods discussed above (1990s, 2000-2007, and 2008-15). Figure 9 only shows results for the 2012-16 period.
} 
all controls included in the regression) than what corruption scores alone would predict. If one were to attach a causal interpretation to these results, one would conclude that high levels of corruption are not a major constraint in the ratings of these countries. Low ratings are instead due to low GDP per capita, high macroeconomic instability, and problems with fiscal and external sustainability. The picture is different for the most recent period (bottom row of Figures 7, 8, and 9). In this case, about half of all IDB borrowing countries are above the regressions line, indicating that these countries have a credit rating which is higher than what would be predicted by their corruption indicators. This finding is consistent with the idea that high levels of corruption could be a major constraint for these countries (see below for a discussion of Mexico and Peru).

While these are interesting patterns, caution should be exercised when assigning a causal interpretation to the regressions of Tables 3-5 and to the results plotted in Figures 6-8. One way to make this point is to augment the basic specification of Tables 3-5 with other governance indicators and then conduct a battery of horserace regressions. Table 6 considers three alternative governance indicators from ICRG (rule of law, investment protection, and bureaucratic quality) and five alternative governance indicators from WGI (government effectiveness, rule of law, regulation, government stability, and voice and accountability). These governance indicators are all highly correlated with each other (the exception is investment protection which, in some cases, has correlation coefficients below 50 percent). This high correlation is consistent with the idea that the various governance indicators are capturing underlying unobservable country characteristics.

When the regressions of Table 3 are augmented with the additional ICRG governance indicators, these indicators tend to be statistically
Table 5: Conditional Correlation between Sovereign Ratings and Transparency International's Control of Corruption Index

\begin{tabular}{lccc}
\hline & $(\mathbf{1})$ & $\mathbf{( 2 )}$ & $\mathbf{( 3 )}$ \\
\hline Corr (TI) & $0.132^{* * *}$ & $0.135^{* * *}$ & $0.139^{* * *}$ \\
& $(0.015)$ & $(0.019)$ & $(0.015)$ \\
\hline In(GDP PC) & $1.199^{* * *}$ & $1.224^{* * *}$ & $1.257^{* * *}$ \\
& $(0.295)$ & $(0.426)$ & $(0.311)$ \\
\hline Debt-to-GDP & $-1.668^{* *}$ & $-1.971^{* * *}$ & $-1.280^{*}$ \\
& $(0.657)$ & $(0.743)$ & $(0.657)$ \\
\hline CA-to-GDP & $15.773^{* * *}$ & $12.507^{* * *}$ & $12.228^{* * *}$ \\
& $(3.243)$ & $(3.601)$ & $(3.675)$ \\
\hline In(infl) & $-0.615^{* *}$ & $-0.807^{* *}$ & $-0.722^{* *}$ \\
& $(0.270)$ & $(0.323)$ & $(0.279)$ \\
\hline Constant & -3.641 & -3.655 & -4.614 \\
& $(2.586)$ & $(3.802)$ & $(2.785)$ \\
\hline Observations & 122 & 107 & 115 \\
\hline R-squared & 0.826 & 0.788 & 0.835 \\
\hline Rating agency & S\&P & Moody's & Fitch \\
\hline Period & $2012-16$ & $2012-16$ & $2012-16$ \\
\hline
\end{tabular}

Source: Author's elaboration based on Fitch, Moody's, Standard \& Poors, TI, and World Bank data.

Notes: * statistically significant at the $10 \%$ confidence level, ${ }^{* *}$ statistically significant at the $5 \%$ confidence level, and ${ }^{* * *}$ statistically significant at the $1 \%$ confidence level.

significant (the exceptions are bureaucratic quality and rule of law in the post-2007 period), and their inclusion in the regressions greatly reduces the magnitude and statistical significance of the point estimates of the corruption indicators (Table 7). When using the WGI corruption indicator, augmenting the regression with any other WGI indicator makes corruption statistically insignificant (Table 8). These findings are consistent with the idea that corruption indicators may capture unobservable underlying country characteristics.

Another way to examine the role of time-invariant country characteristics is to pool a different country-year into a panel where each country is observed more than once over different time periods. This panel data structure can be used 

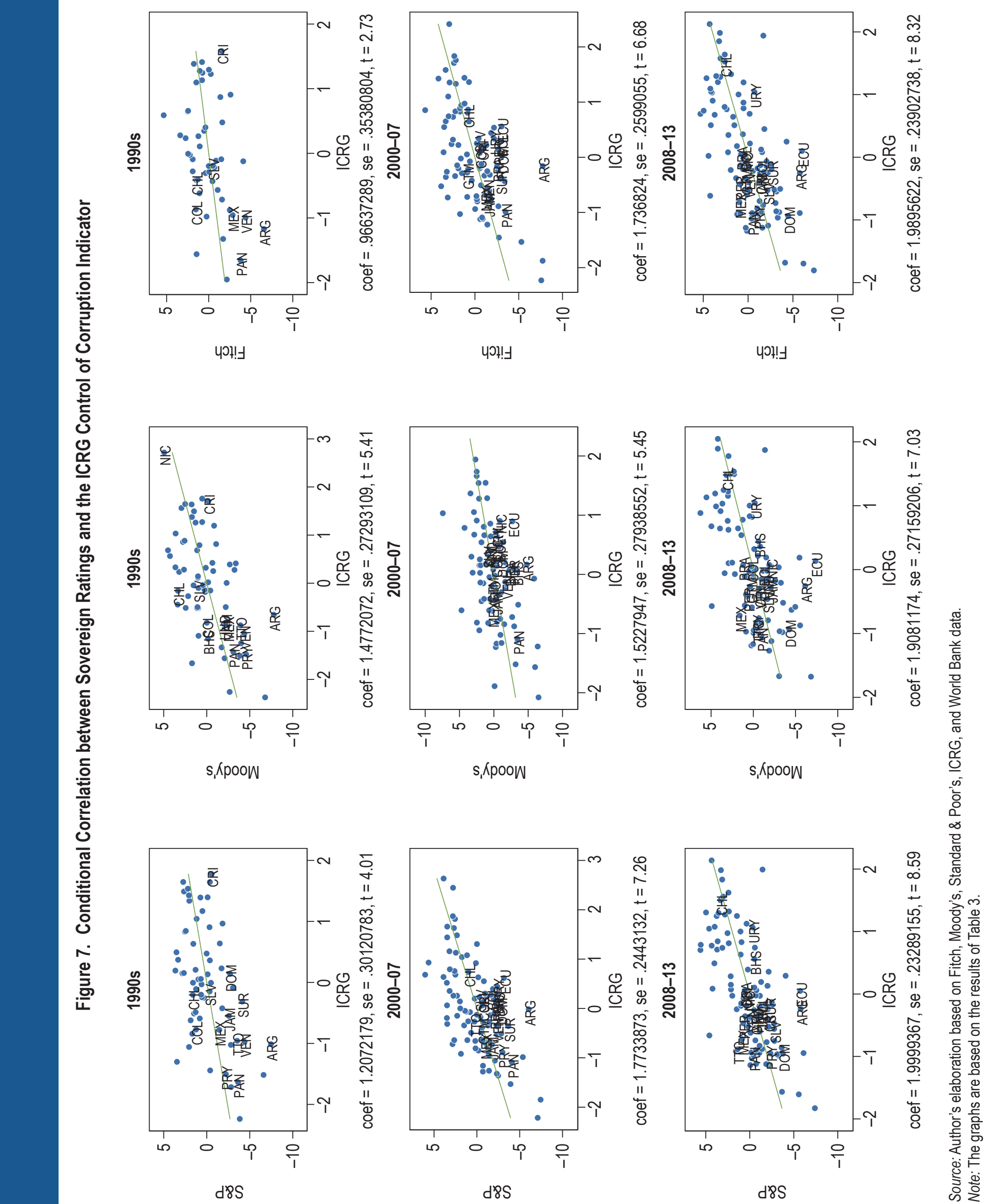


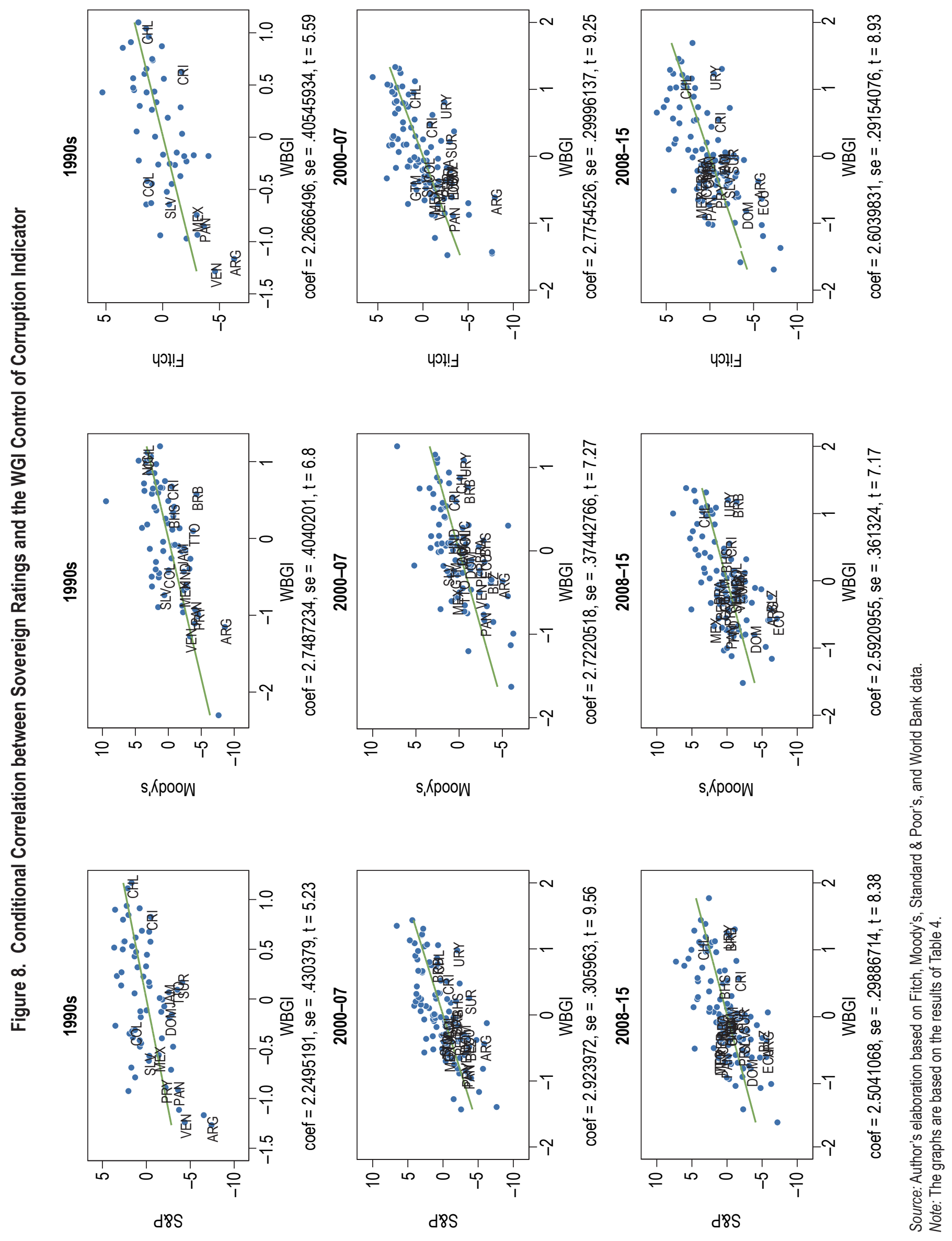


Figure 9. Conditional Correlation between Sovereign Ratings and Tl's Corruption Perception Index

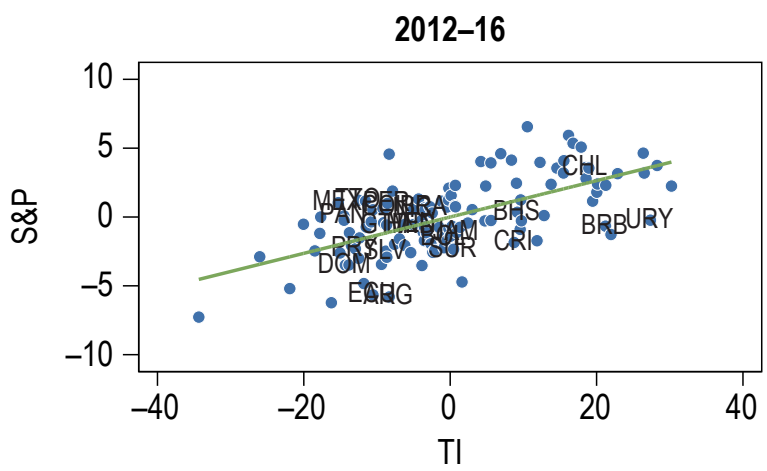

coef $=.13196686$, se $=.01508476, t=8.75$

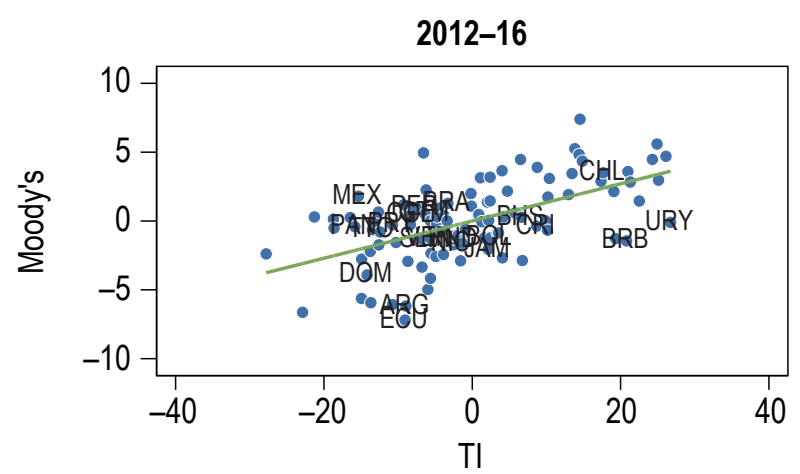

coef $=.1352146, \mathrm{se}=.01873137, \mathrm{t}=7.22$

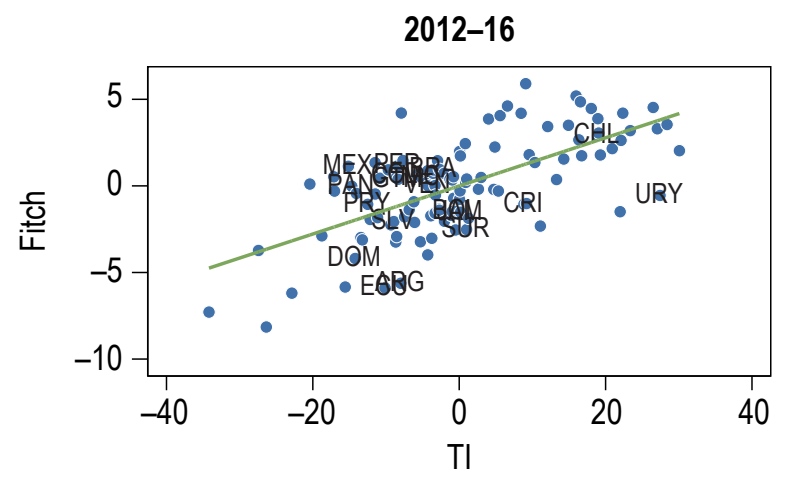

coef $=.1388751$, se $=.0152246, t=9.12$

Source: Author's elaboration based on Fitch, Moody's, Standard \& Poor's, TI, and World Bank data.

Note: The graphs are based on the results of Table 5.

to estimate a fixed-effects regression, which allows all time-invariant country characteristics (such as cultural background, trust in institutions, and social capital) that may bias the estimated correlation between corruption indicators and credit ratings to be implicitly accounted for. The fixed-effect results are thus robust to controlling for all possible unobservable underlying country characteristics that do not vary over time. When a set of fixed-effects models are estimated by pooling the three periods together, the corruption indicators are positively correlated with credit ratings, but the correlation is statistically significant only for two out of six regressions (Table 9).

The finding that the WGI corruption indicator is robustly correlated with Moody's and Fitch ratings is consistent with the fact that these two agencies use WGI scores as direct input in their rating methodology. Specifically, the WGI control of corruption score is one of the quantitative criteria (together with other WGIs) for Moody's Intuitional Strength Assessment and Fitch's Structural Assessment. Therefore, an increase in the worldwide control of corruption score is mechanically reflected in an increase in Moody's and Fitch ratings, even controlling for all possible time-invariant unobservable country characteristics.

By contrast, Standard and Poor's does not use clear quantitative criteria to evaluate the effect of corruption on its rating opinions, and none of the three main rating agencies uses ICRG scores in their methodology. Consequently, 
Table 6: Correlation among Governance Indicators

\begin{tabular}{|c|c|c|c|c|c|c|c|c|c|c|}
\hline & \multicolumn{4}{|c|}{ ICRG } & \multicolumn{6}{|c|}{ WGI } \\
\hline & $\mathrm{CoC}$ & RoL & IP & $B Q$ & $\mathrm{CoC}$ & Eff & $\mathrm{CoC}$ & Reg & Gov & Voice \\
\hline Control of Corruption (ICRG) & 1.00 & & & & & & & & & \\
\hline Rule of Law (ICRG) & $0.69^{* * *}$ & 1.00 & & & & & & & & \\
\hline Investment protection (ICRG) & $0.38^{* * *}$ & $0.49^{* * *}$ & 1.00 & & & & & & & \\
\hline Bureaucratic Quality (ICRG) & $0.73^{* * *}$ & $0.66^{* * *}$ & $0.59^{* * *}$ & 1.00 & & & & & & \\
\hline Control of Corruption (WGI) & $0.85^{\star * *}$ & $0.76^{* * *}$ & $0.62^{* * *}$ & $0.83^{* * *}$ & 1.00 & & & & & \\
\hline Government Effectiveness (WGI) & $0.79^{* * *}$ & $0.75^{* * *}$ & $0.67^{* * *}$ & $0.90^{* * *}$ & $0.94^{* * *}$ & 1.00 & & & & \\
\hline Rule of Law (WGI) & $0.80^{* * *}$ & $0.81^{* * *}$ & $0.68^{* * *}$ & $0.85^{* * *}$ & $0.94^{* * *}$ & $0.93^{* * *}$ & 1.00 & & & \\
\hline Regulation (WGI) & $0.73^{* * *}$ & $0.68^{* * *}$ & $0.72^{\star * *}$ & $0.81^{* * *}$ & $0.87^{* * *}$ & $0.94^{* * *}$ & $0.89^{* * *}$ & 1.00 & & \\
\hline Government Stability (WGI) & $0.66^{\star * \star}$ & $0.72^{* * *}$ & $0.58^{* * *}$ & $0.65^{\star * *}$ & $0.75^{\star * \star}$ & $0.72^{* * *}$ & $0.81^{* * *}$ & $0.67^{* * *}$ & 1.00 & \\
\hline Voice and Accountability (WGI) & $0.72^{* * *}$ & $0.54^{* * *}$ & $0.57^{* * *}$ & $0.75^{* * *}$ & $0.79^{* * *}$ & $0.79^{* * *}$ & $0.84^{* * *}$ & $0.80^{* * *}$ & $0.73^{* * *}$ & 1.00 \\
\hline
\end{tabular}

Source: Author's elaboration based on ICRG, TI, and World Bank data.

Notes: ${ }^{* * *}$ indicates that the correlation is statistically significant at the $1 \%$ confidence level.

Table 7: Conditional Correlation between Sovereign Ratings and the ICRG Corruption Indicator Controlling for other Governance Indicators

\begin{tabular}{|c|c|c|c|c|c|c|}
\hline & (1) & (2) & (3) & (4) & (5) & (6) \\
\hline Corr (ICRG) & $\begin{array}{l}0.602^{* *} \\
(0.260)\end{array}$ & $\begin{array}{c}0.358 \\
(0.317)\end{array}$ & $\begin{array}{c}0.566^{*} \\
(0.297)\end{array}$ & $\begin{array}{l}1.100^{* * *} \\
(0.299)\end{array}$ & $\begin{array}{l}1.212^{* * *} \\
(0.353)\end{array}$ & $\begin{array}{l}1.109^{* * *} \\
(0.312)\end{array}$ \\
\hline Ln (GDP PC) & $\begin{array}{c}0.622^{*} \\
(0.326)\end{array}$ & $\begin{array}{l}1.081^{* *} \\
(0.446)\end{array}$ & $\begin{array}{l}1.059^{* * *} \\
(0.314)\end{array}$ & $\begin{array}{l}0.768^{\star *} \\
(0.301)\end{array}$ & $\begin{array}{l}0.869^{* *} \\
(0.400)\end{array}$ & $\begin{array}{l}1.039^{* * *} \\
(0.305)\end{array}$ \\
\hline Debt-to-GDP & $\begin{array}{r}-1.160^{*} \\
(0.632)\end{array}$ & $\begin{array}{l}-1.987^{\star * \star} \\
(0.699)\end{array}$ & $\begin{array}{c}-1.485^{\star \star} \\
(0.661)\end{array}$ & $\begin{array}{c}-1.617^{\star *} \\
(0.646)\end{array}$ & $\begin{array}{l}-1.787^{* *} \\
(0.724)\end{array}$ & $\begin{array}{c}-1.396^{\star *} \\
(0.650)\end{array}$ \\
\hline CA-to-GDP & $\begin{array}{c}6.290^{* *} \\
(2.829)\end{array}$ & $\begin{array}{c}0.159 \\
(3.230)\end{array}$ & $\begin{array}{l}5.491^{*} \\
(3.187)\end{array}$ & $\begin{array}{l}12.585^{* * *} \\
(3.160)\end{array}$ & $\begin{array}{l}9.075^{* *} \\
(3.573)\end{array}$ & $\begin{array}{l}10.856^{* * *} \\
(3.364)\end{array}$ \\
\hline In(infl) & $\begin{array}{c}-0.519^{*} \\
(0.272)\end{array}$ & $\begin{array}{r}-0.628^{*} \\
(0.362)\end{array}$ & $\begin{array}{c}-0.765^{\star *} \\
(0.299)\end{array}$ & $\begin{array}{c}-0.251 \\
(0.262)\end{array}$ & $\begin{array}{c}-0.486 \\
(0.303)\end{array}$ & $\begin{array}{c}-0.290 \\
(0.274)\end{array}$ \\
\hline ICRG_law & $\begin{array}{l}0.880^{* * *} \\
(0.237)\end{array}$ & $\begin{array}{l}0.578^{* *} \\
(0.250)\end{array}$ & $\begin{array}{l}0.538^{* *} \\
(0.224)\end{array}$ & $\begin{array}{c}0.441^{*} \\
(0.224)\end{array}$ & $\begin{array}{c}0.235 \\
(0.253)\end{array}$ & $\begin{array}{c}0.332 \\
(0.222)\end{array}$ \\
\hline ICRG_investment & $\begin{array}{l}0.834^{* * *} \\
(0.162)\end{array}$ & $\begin{array}{l}0.802^{* * *} \\
(0.198)\end{array}$ & $\begin{array}{l}0.863^{\star * *} \\
(0.183)\end{array}$ & $\begin{array}{l}0.770^{* * *} \\
(0.157)\end{array}$ & $\begin{array}{l}0.953^{\star * *} \\
(0.179)\end{array}$ & $\begin{array}{l}0.811^{* * *} \\
(0.161)\end{array}$ \\
\hline ICRG_bureau & $\begin{array}{l}1.137^{\star * *} \\
(0.333)\end{array}$ & $\begin{array}{l}1.619^{* * *} \\
(0.419)\end{array}$ & $\begin{array}{c}0.991^{* *} \\
(0.383)\end{array}$ & $\begin{array}{r}0.660^{*} \\
(0.357) \\
\end{array}$ & $\begin{array}{c}0.329 \\
(0.421)\end{array}$ & $\begin{array}{c}0.558 \\
(0.353) \\
\end{array}$ \\
\hline Constant & $\begin{array}{l}-7.527^{\star * *} \\
(2.385) \\
\end{array}$ & $\begin{array}{c}-10.480^{* * *} \\
(3.192) \\
\end{array}$ & $\begin{array}{l}-9.503^{* * *} \\
(2.640) \\
\end{array}$ & $\begin{array}{c}-6.759^{* * *} \\
(2.533) \\
\end{array}$ & $\begin{array}{c}-7.689^{* *} \\
(3.353) \\
\end{array}$ & $\begin{array}{l}-9.177^{* * *} \\
(2.683) \\
\end{array}$ \\
\hline Observations & 97 & 86 & 92 & 109 & 99 & 106 \\
\hline R-squared & 0.901 & 0.880 & 0.895 & 0.876 & 0.849 & 0.878 \\
\hline Rating agency & S\&P & Moody's & Fitch & S\&P & Moody's & Fitch \\
\hline Period & 2000-07 & 2000-07 & 2000-07 & $2008-13$ & 2008-13 & 2008-13 \\
\hline
\end{tabular}

Source: Author's elaboration based on Fitch, Moody's, Standard \& Poors, ICRG, and World Bank data.

Notes: * statistically significant at the $10 \%$ confidence level, ${ }^{* *}$ statistically significant at the $5 \%$ confidence level, and ${ }^{* * *}$ statistically significant at the $1 \%$ confidence level. 
Table 8: Conditional Correlation between Sovereign Ratings and the WGI Corruption Indicator Controlling for the Rule of Law WGI Indicator

\begin{tabular}{|c|c|c|c|c|c|c|}
\hline & (1) & (2) & (3) & (4) & (5) & (6) \\
\hline Corr (WGI) & $\begin{array}{c}0.604 \\
(0.729)\end{array}$ & $\begin{array}{c}0.766 \\
(0.814)\end{array}$ & $\begin{array}{c}0.916 \\
(0.741)\end{array}$ & $\begin{array}{c}-0.422 \\
(0.650)\end{array}$ & $\begin{array}{c}0.190 \\
(0.769)\end{array}$ & $\begin{array}{c}0.002 \\
(0.662)\end{array}$ \\
\hline $\ln (G D P P C)$ & $\begin{array}{l}1.043^{* * *} \\
(0.301)\end{array}$ & $\begin{array}{l}1.524^{* * *} \\
(0.448)\end{array}$ & $\begin{array}{l}1.406^{* * *} \\
(0.289)\end{array}$ & $\begin{array}{l}0.770^{* *} \\
(0.300)\end{array}$ & $\begin{array}{c}0.820^{*} \\
(0.437)\end{array}$ & $\begin{array}{l}0.899^{* * *} \\
(0.295)\end{array}$ \\
\hline Debt-to-GDP & $\begin{array}{c}-1.807^{* * *} \\
(0.615)\end{array}$ & $\begin{array}{c}-1.701^{* *} \\
(0.711)\end{array}$ & $\begin{array}{c}-1.236^{*} \\
(0.641)\end{array}$ & $\begin{array}{c}-2.138^{* * *} \\
(0.628)\end{array}$ & $\begin{array}{l}-2.379^{* * *} \\
(0.725)\end{array}$ & $\begin{array}{c}-1.576^{* *} \\
(0.621)\end{array}$ \\
\hline CA-to-GDP & $\begin{array}{l}5.809^{* *} \\
(2.702)\end{array}$ & $\begin{array}{c}-1.772 \\
(3.203)\end{array}$ & $\begin{array}{c}1.115 \\
(3.033)\end{array}$ & $\begin{array}{l}16.575^{\star * *} \\
(3.055)\end{array}$ & $\begin{array}{l}13.331^{* * *} \\
(3.520)\end{array}$ & $\begin{array}{l}13.983^{\star * *} \\
(3.335)\end{array}$ \\
\hline $\ln ($ infl) & $\begin{array}{c}-0.679^{* *} \\
(0.266) \\
\end{array}$ & $\begin{array}{c}-0.875^{\star *} \\
(0.348)\end{array}$ & $\begin{array}{l}-0.914^{* * *} \\
(0.279) \\
\end{array}$ & $\begin{array}{c}-0.413 \\
(0.259) \\
\end{array}$ & $\begin{array}{c}-0.470 \\
(0.319) \\
\end{array}$ & $\begin{array}{l}-0.553^{* *} \\
(0.265)\end{array}$ \\
\hline Rule of Law (WGI) & $\begin{array}{l}2.934^{* * *} \\
(0.845)\end{array}$ & $\begin{array}{l}2.483^{* * *} \\
(0.925)\end{array}$ & $\begin{array}{l}2.273^{\star * *} \\
(0.834)\end{array}$ & $\begin{array}{l}3.691^{* * *} \\
(0.744)\end{array}$ & $\begin{array}{l}3.122^{* * *} \\
(0.894)\end{array}$ & $\begin{array}{c}3.186^{* * *} \\
(0.740)\end{array}$ \\
\hline Constant & $\begin{array}{c}3.835 \\
(2.762)\end{array}$ & $\begin{array}{l}-0.479 \\
(4.219)\end{array}$ & $\begin{array}{c}0.713 \\
(2.754)\end{array}$ & $\begin{array}{l}6.126^{* *} \\
(2.845)\end{array}$ & $\begin{array}{c}5.881 \\
(4.238)\end{array}$ & $\begin{array}{c}4.807^{*} \\
(2.840)\end{array}$ \\
\hline Observations & 108 & 91 & 100 & 123 & 108 & 115 \\
\hline R-squared & 0.868 & 0.851 & 0.879 & 0.848 & 0.807 & 0.857 \\
\hline Rating agency & S\&P & Moody's & Fitch & S\&P & Moody's & Fitch \\
\hline Period & $2000-07$ & $2000-07$ & $2000-07$ & 2008-15 & 2008-15 & 2008-15 \\
\hline
\end{tabular}

Source: Author's elaboration based on Fitch, Moody's, Standard \& Poors, and World Bank data.

Notes: * statistically significant at the $10 \%$ confidence level, ${ }^{* *}$ statistically significant at the $5 \%$ confidence level, and ${ }^{* * *}$ statistically significant at the $1 \%$ confidence level.

Table 9: Conditional Correlation between Sovereign Ratings and Corruption Indicators

\begin{tabular}{lcccccc}
\hline & $\mathbf{( 1 )}$ & $\mathbf{( 2 )}$ & $\mathbf{( 3 )}$ & $\mathbf{( 4 )}$ & $\mathbf{( 5 )}$ & $\mathbf{( 6 )}$ \\
\hline CORR & 0.252 & 0.326 & -0.008 & 0.264 & $2.020^{* * *}$ & $1.249^{* *}$ \\
& $(0.214)$ & $(0.272)$ & $(0.217)$ & $(0.464)$ & $(0.569)$ & $(0.501)$ \\
\hline In(GDP PC) & $3.827^{* * *}$ & $4.374^{* * *}$ & $3.903^{* * *}$ & $3.824^{* * *}$ & $4.362^{* * *}$ & $2.233^{* * *}$ \\
& $(0.692)$ & $(0.911)$ & $(0.712)$ & $(0.729)$ & $(0.865)$ & $(0.720)$ \\
\hline Debt-to-GDP & $-4.036^{* * *}$ & $-3.189^{* * *}$ & $-3.219^{* * *}$ & $-3.484^{* * *}$ & $-3.137^{* * *}$ & $-2.854^{* * *}$ \\
& $(0.507)$ & $(0.636)$ & $(0.493)$ & $(0.519)$ & $(0.606)$ & $(0.520)$ \\
\hline CA-to-GDP & 1.579 & -0.713 & 1.735 & 2.433 & -1.710 & 2.457 \\
& $(1.958)$ & $(2.618)$ & $(2.171)$ & $(2.048)$ & $(2.455)$ & $(2.288)$ \\
\hline In(infl) & $-0.298^{* *}$ & 0.106 & -0.111 & $-0.278^{*}$ & 0.252 & 0.156 \\
& $(0.137)$ & $(0.170)$ & $(0.134)$ & $(0.144)$ & $(0.161)$ & $(0.137)$ \\
\hline Observations & 269 & 250 & 247 & 295 & 268 & 266 \\
\hline Number of countries & 109 & 101 & 106 & 123 & 111 & 115 \\
\hline Rating agency & S\&P & Moody's & Fitch & S\&P & Moody's & Fitch \\
\hline Corruption indicator & ICRG & ICRG & ICRG & WGI & WGI & WGI \\
\hline
\end{tabular}

Source: Author's elaboration based on Fitch, Moody's, Standard \& Poors, ICRG, and World Bank data.

Notes: All regressions include country and period fixed effects, ${ }^{*}$ statistically significant at the $10 \%$ confidence level, ${ }^{* *}$ statistically significant at the $5 \%$ confidence level, and ${ }^{* * *}$ statistically significant at the $1 \%$ confidence level. 
there is no mechanical effect of ICRG control of corruption score on credit ratings or a mechanical effect of any governance indicator on Standard and Poor's ratings. The results of the fixed-effect panel regressions that control for time-invariant unobservable country characteristics reflect these characteristics of the various rating methodologies. Thus, they find no correlation between control of corruption indicators and Standard and Poor's rating opinions or between the ICRG control of corruption score and Fitch and Moody's rating opinions.

In the last exercise, the regressions of Tables $3-5$ are repeated by substituting the simple linear coding of sovereign ratings (where a onenotch increase corresponds to one extra point in the indicator on a 1-21 scale) with the nonlinear implied probability of default plotted in Figure 2 . The results (reported in Figures 10-12) show a much weaker correlation between corruption indicators and sovereign ratings. The slope of the relationship is always lower (in some case the line is flat, indicating no relationship between corruption scores and ratings) than in the linear case and the confidence intervals are wider. In fact, in one third of the estimated models ( 7 out of 21), the relationship between control of corruption and sovereign ratings is not statistically significant at the 5 percent confidence level. This suggests that, for the average country in the sample, the correlation between corruption and ratings happens at a point in which the curves of Figure 2 are flat (i.e., when the default probability does not vary much along the rating scale). 

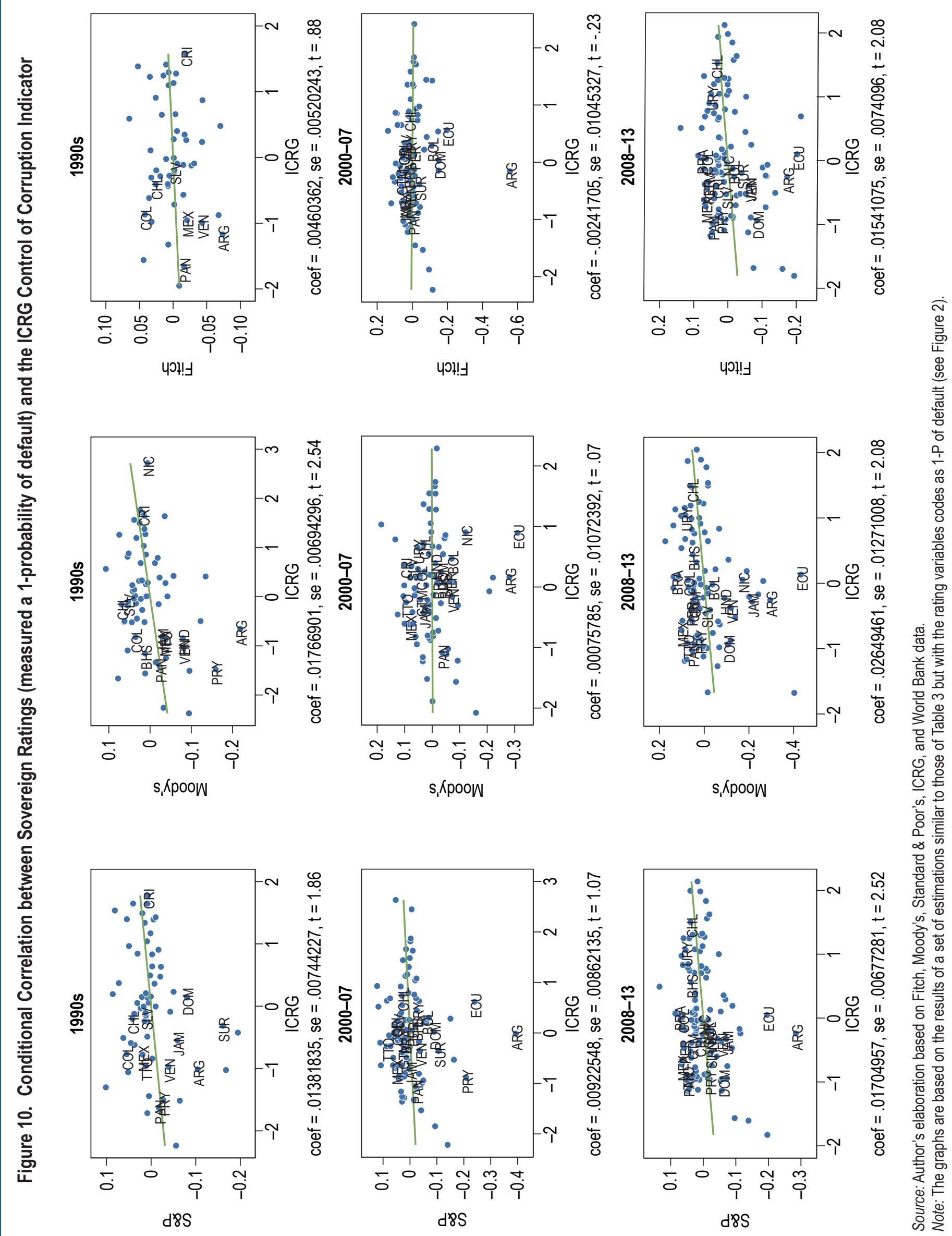

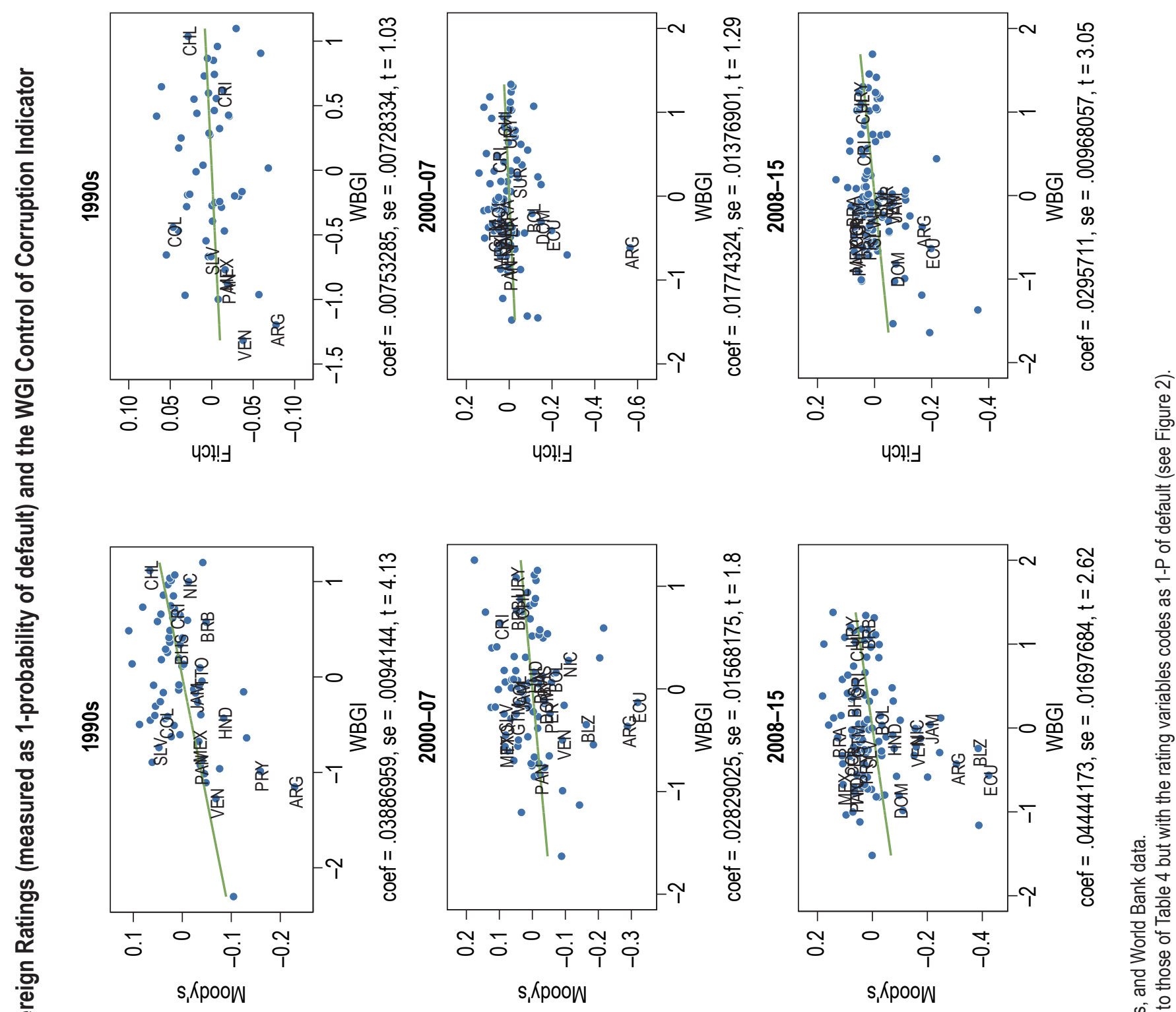

के
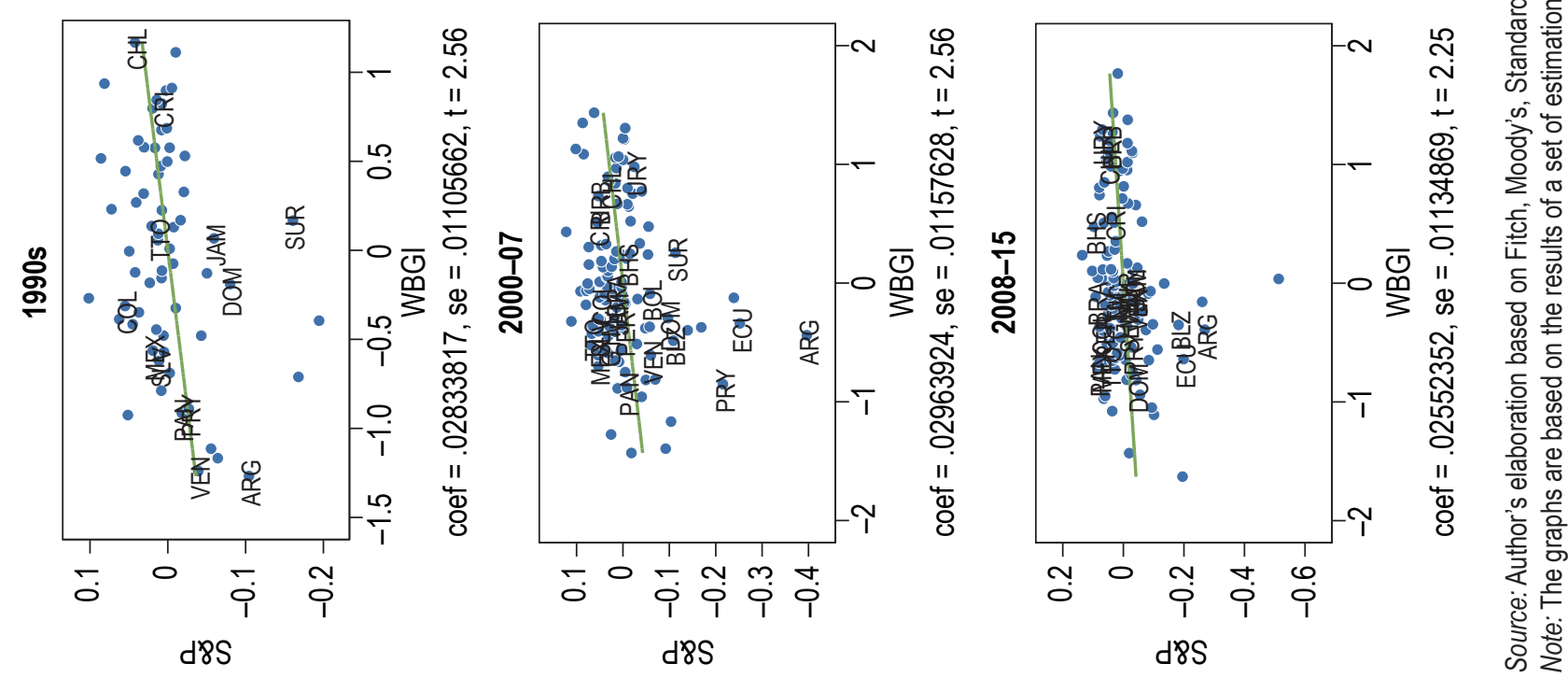
Figure 12. Conditional Correlation between Sovereign Ratings (measured as 1-probability of default) and Tl's Corruption Perception Index
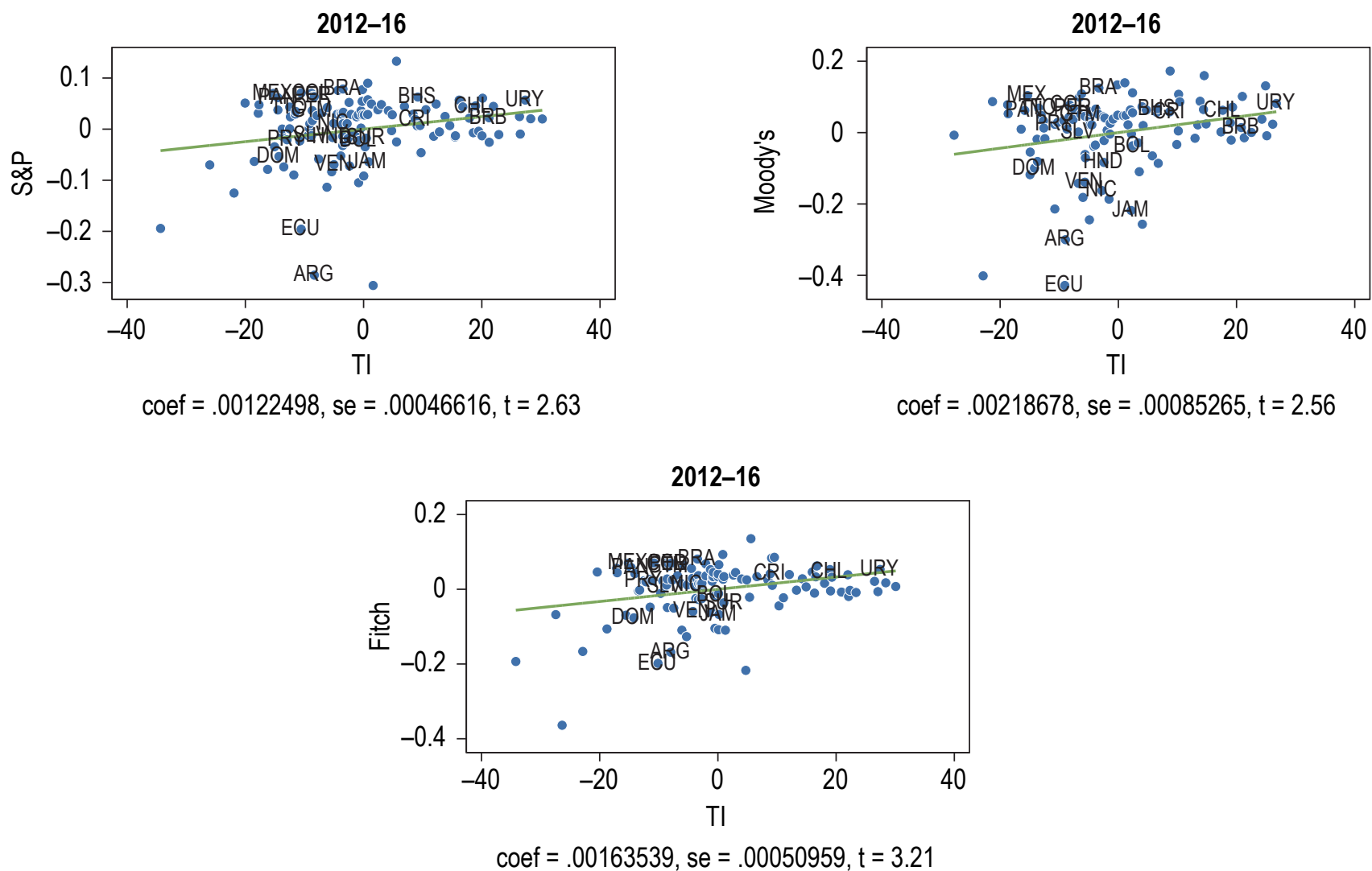

Source: Author's elaboration based on Fitch, Moody's, Standard \& Poor's, TI, and World Bank data.

Note: The graphs are based on the results of a set of estimations similar to those of Table 5 but with the rating variables codes as 1-P of default (see Figure 2). 


\section{HOW SOVEREIGN RATING METHODOLOGIES INCORPORATE CORRUPTION INDICATORS}

redit rating agencies assess sovereign risk by using a mix of quantitative and qualitative judgments aimed at capturing sovereign capacity and willingness to meet debt obligations. This section provides a brief description of the methodologies of the three main credit rating agencies and discusses how these methodologies incorporate corruption indicators. Table 10 summarizes the results.

While all three agencies incorporate corruption indicators in their rating criteria, there are differences in the way in which corruption indicators affect the ratings issued by these agencies. While Fitch has well-defined quantitative criteria for incorporating corruption in its rating opinions, Standard \& Poor's favors a more qualitative assessment of the risks arising from corruption. Moody's approach lies somewhere in between these two approaches.

Another difference among the three rating agencies is that Fitch uses an additive model in which the final rating is close to the sum of the various indicators included in the methodology. Hence, overperformance in one indicator can compensate for underperformance in another indicator, and it is less likely that any given indicator will be a binding constraint for a country's sovereign rating. Fitch's methodology is close (albeit more sophisticated) to the linear regression approach adopted in Section 3 of this paper. Standard \& Poor's and Moody's aggregate the various indicators by using double entry tables. This approach leads to nonlinearities and is more likely to create a situation

Table 10: Corruption Indicators in Sovereign Rating Methodologies

\begin{tabular}{|c|c|c|c|}
\hline \multirow[b]{2}{*}{ Agency } & \multicolumn{2}{|c|}{ No. of rated sovereigns in 2016} & \multirow[b]{2}{*}{ Are corruption indicators included in the methodology? } \\
\hline & Total & IDB borrowing countries & \\
\hline $\begin{array}{l}\text { Standard \& } \\
\text { Poor's }\end{array}$ & 132 & 24 & $\begin{array}{l}\text { Yes, in a qualitative manner as a part of the sovereign Political score. } \\
\text { The latest methodology (December 2014) does not specify any data } \\
\text { source. However, the June } 2011 \text { methodology mentions the Worldwide } \\
\text { Governance Indicators and Transparency International's Corruption } \\
\text { Perception index as sources for corruption and governance data. }\end{array}$ \\
\hline Moody's & 109 & 22 & $\begin{array}{l}\text { Yes, in a quantitative manner as a part of the Institutional Framework } \\
\text { and Effectiveness rating subfactor. Moody's uses the Control of } \\
\text { Corruption index provided by the Worldwide Governance Indicators. }\end{array}$ \\
\hline Fitch & 124 & 19 & $\begin{array}{l}\text { Yes, in a quantitative manner as a part of the overall governance } \\
\text { indicator included in the Structural analytical pillar. The data are from } \\
\text { the Worldwide Governance Indicators }\end{array}$ \\
\hline
\end{tabular}

Source: Author's analysis of Fitch, Moody's, and Standard \& Poors methodologies. 
in which a given indicator is a binding constraint for a country's rating.

\subsection{Standard \& Poor's}

The following five factors are the bases for Standard \& Poor's sovereign analysis (Standard \& Poor's, 2014): (i) Institutional assessment; (ii) Economic assessment; (iii) External assessment; (iv) Fiscal assessment; and (v) Monetary assessment (Figure 13a).

As a first step, Standard \& Poor's analysts assign a numerical score to each factor, which is then validated by the Rating Committee. These scores, which range between 1 (strongest) and 6 (weakest), are based on a series of quantitative and qualitative criteria specified in the rating methodology.

In the next step, the scores of the institutional and economic assessments are averaged to form the institutional and economic profile, and the external, fiscal, and monetary assessment scores are averaged to form the flexibility and performance profile. An indicative rating level is then obtained from a double entry table, which maps the scores of the two profiles into credit rating levels (Figure 13b).

In the final step, the Rating Committee decides whether the indicative rating should be adjusted based on factors not fully captured in the credit scoring process described above. Absent exceptional factors, the final rating will be within one notch of the indicative rating produced by the double entry table.

According to Standard \& Poor's, corruption matters for sovereign rating because, "The perceived level of corruption in the country correlates strongly with the accountability of its institutions" (Standard \& Poor's, 2014: 12). In the methodology, a country's level of corruption affects the score of the Institutional Assessment factor. Specifically, impaired transparency and accountability of institutions owing to moderate to high levels of corruption contributes to a score of 5 or 6 (the weakest scores) in Standard \& Poor's Institutional Assessment. However, S\&P neither specifies a quantitative threshold for the corruption indicator nor refers to any specific corruption indicator. ${ }^{17}$ In fact, S\&P is clear in stating that its institutional assessment is mostly based on a qualitative analysis. $^{18}$

\subsection{Moody's}

Moody's rating methodology is divided into four broad rating factors which then comprise 14 subfactors and more than 30 specific indicators. The four main factors are: (i) economic strength; (ii) institutional strength; (iii) fiscal strength; and (iv) susceptibility to event risk (top left panel of Figure 14).

There are several steps in the rating methodology. Moody's analysts start by using the subfactors to score each main factor on a 0-100 scale. This numerical scale is then translated into a qualitative scale, which consists of 14 strength categories (from VL-, very low minus, to $\mathrm{VH}+$, very high plus). Next, analysts use a double entry table to combine the economic strength and institutional strength assessments into an economic resiliency assessment (top right panel of Figure 14). In the third step, the economic resiliency assessment is combined with the fiscal strength assessment to form the government

\footnotetext{
${ }^{17}$ In the 2011 methodology there was a reference to the WGIs and to TI's Corruption Perception Index. However, the 2014 methodology does not cite any specific data source.

18 "The assessment of these factors relies mostly on our qualitative analysis." (Standard \& Poor's, 2014: 11).
} 
Figure 13. S\&P Sovereign Rating Framework and Aggregation of the Two Profiles

\section{a. Sovereign Issuer Credit Rating Framework}

Five key areas to detemine a sovereign's creditworthiness
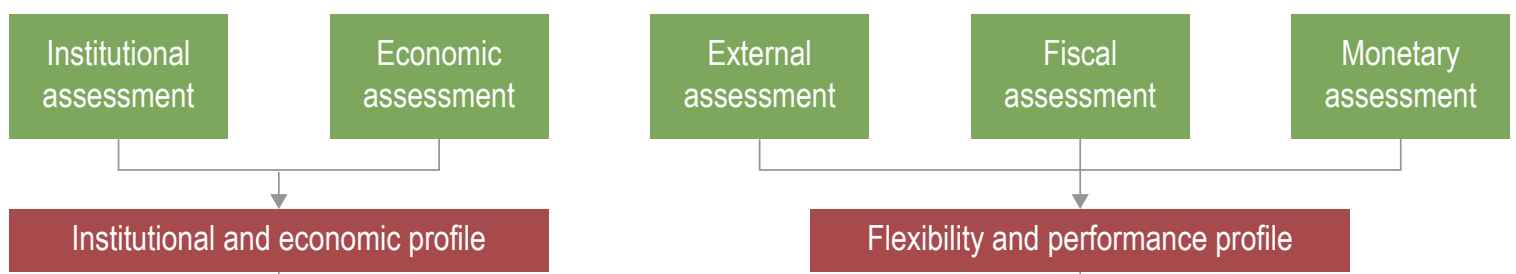

Flexibility and performance profile

Sovereign indicative rating level

Foreign-currency sovereign rating

Supplemental adjustment factors and one notch of uplift/downlift, if applicable

Foreign-currency sovereign rating

Zero to two notches of uplift

Local-currency sovereign rating

\section{b. Indicative Rating Levels from the Combination of the Institutional and \\ Economic Profile with the Flexibility and Performance Profile}

\begin{tabular}{|c|c|c|c|c|c|c|c|c|c|c|c|c|}
\hline \multicolumn{13}{|c|}{ Institutional and economic profile } \\
\hline $\begin{array}{l}\text { Flexibility and } \\
\text { performance } \\
\text { profile }\end{array}$ & 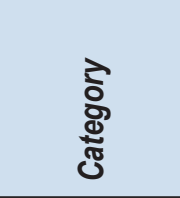 & $\begin{array}{l}\text { 흔 } \\
\text { ळ } \\
\text { ळ }\end{array}$ & 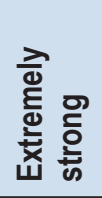 & 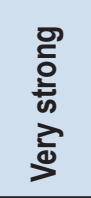 & $\begin{array}{l}\text { 모 } \\
\text { 은 } \\
\text { ๘ }\end{array}$ & 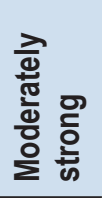 & 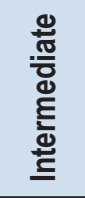 & 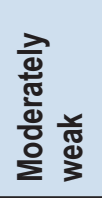 & 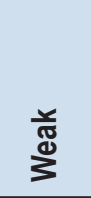 & 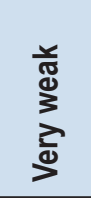 & 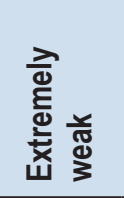 & 흥 \\
\hline Category & Assessment & 1 & 1.5 & 2 & 2.5 & 3 & 3.5 & 4 & 4.5 & 5 & 5.5 & 6 \\
\hline Extremely strong & 1 to 1.7 & aaa & aaa & aaa & $a a+$ & aa & a+ & a & $a-$ & $\mathrm{bbb}+$ & $\mathrm{N} / \mathrm{A}$ & $\mathrm{N} / \mathrm{A}$ \\
\hline Very strong & 1.8 to 2.2 & aaa & aaa & aat & aa & aa- & a & a- & $\mathrm{bbb}+$ & $\mathrm{bbb}$ & $b b+$ & $b b-$ \\
\hline Strong & 2.3 to 2.7 & aaa & aa+ & aа & aa- & a & $a-$ & bbb+ & $\mathrm{bbb}$ & $\mathrm{bb}+$ & $\mathrm{bb}$ & $b+$ \\
\hline Moderately strong & 2.8 to 3.2 & aat & aа & aa- & a+ & $a-$ & $\mathrm{bbb}$ & $\mathrm{bbb}-$ & $\mathrm{bb}+$ & $\mathrm{bb}$ & $b b-$ & $b+$ \\
\hline Intermediate & 3.3 to 3.7 & aa & aa- & $a+$ & a & $\mathrm{bbb}+$ & $\mathrm{bbb}-$ & $\mathrm{bb}+$ & $\mathrm{bb}$ & $\mathrm{bb}-$ & $b+$ & $b$ \\
\hline Moderately weak & 3.8 to 4.2 & aа- & $a^{+}$ & a & $\mathrm{bbb+}$ & $\mathrm{bbb}$ & $\mathrm{bb}+$ & $\mathrm{bb}$ & $\mathrm{bb}-$ & $b+$ & b & b \\
\hline Weak & 4.3 to 4.7 & a & $a-$ & $\mathrm{bbb}+$ & bbb & $\mathrm{bb}+$ & $\mathrm{bb}$ & $b b-$ & $b+$ & $b$ & $b-$ & $b-$ \\
\hline Very weak & 4.8 to 5.2 & $\mathrm{~N} / \mathrm{A}$ & $\mathrm{bbb}$ & $\mathrm{bbb}-$ & $b b+$ & $\mathrm{bb}$ & $\mathrm{bb}-$ & $b+$ & $b$ & $b$ & $b-$ & $b-$ \\
\hline Extremely weak & 5.3 to 6 & $\mathrm{~N} / \mathrm{A}$ & $\mathrm{bb}+$ & $\mathrm{bb}$ & $\mathrm{bb}-$ & $b+$ & $b$ & $b$ & $b-$ & $b-$ & $\begin{array}{l}\text { 'b-' and } \\
\text { below }\end{array}$ & $\begin{array}{c}\text { 'b-' and } \\
\text { below }\end{array}$ \\
\hline
\end{tabular}

Assigning 'CCC+', 'CCC', 'CCC-', and 'CC' ratings is based on "Criteria for Assigning 'CCC+', 'CCC', 'CCC-', and 'CC' Ratings," Oct. 1, 2012. 


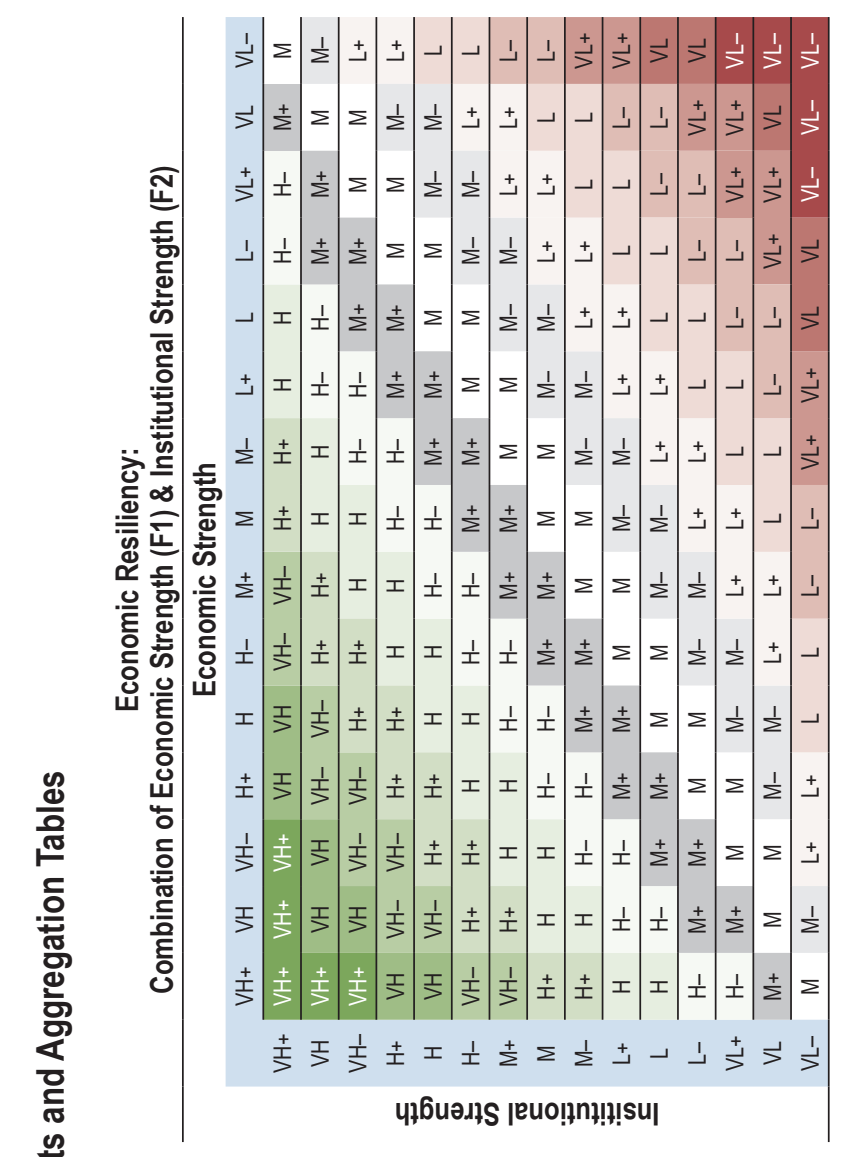

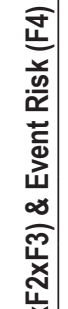

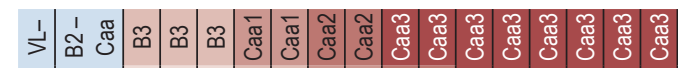

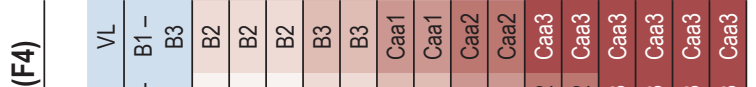

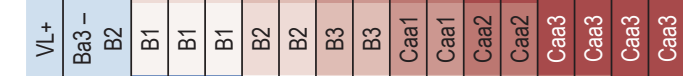

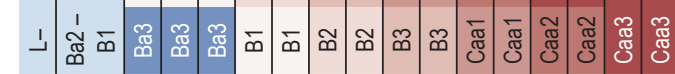

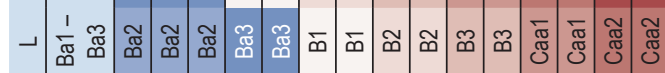

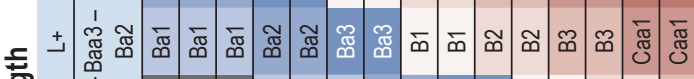

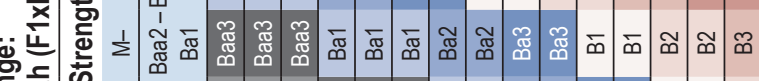

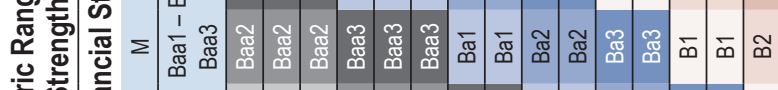

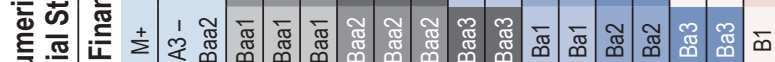

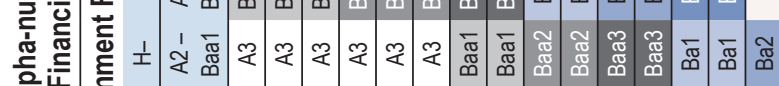
은핸

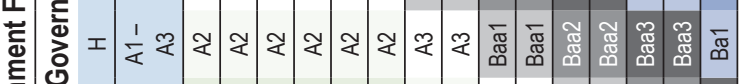

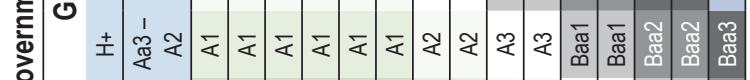

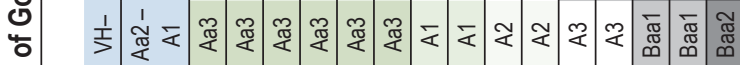
音

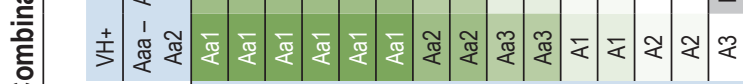

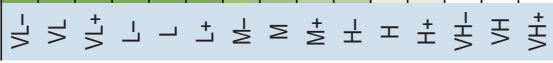

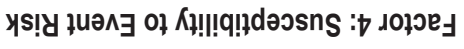

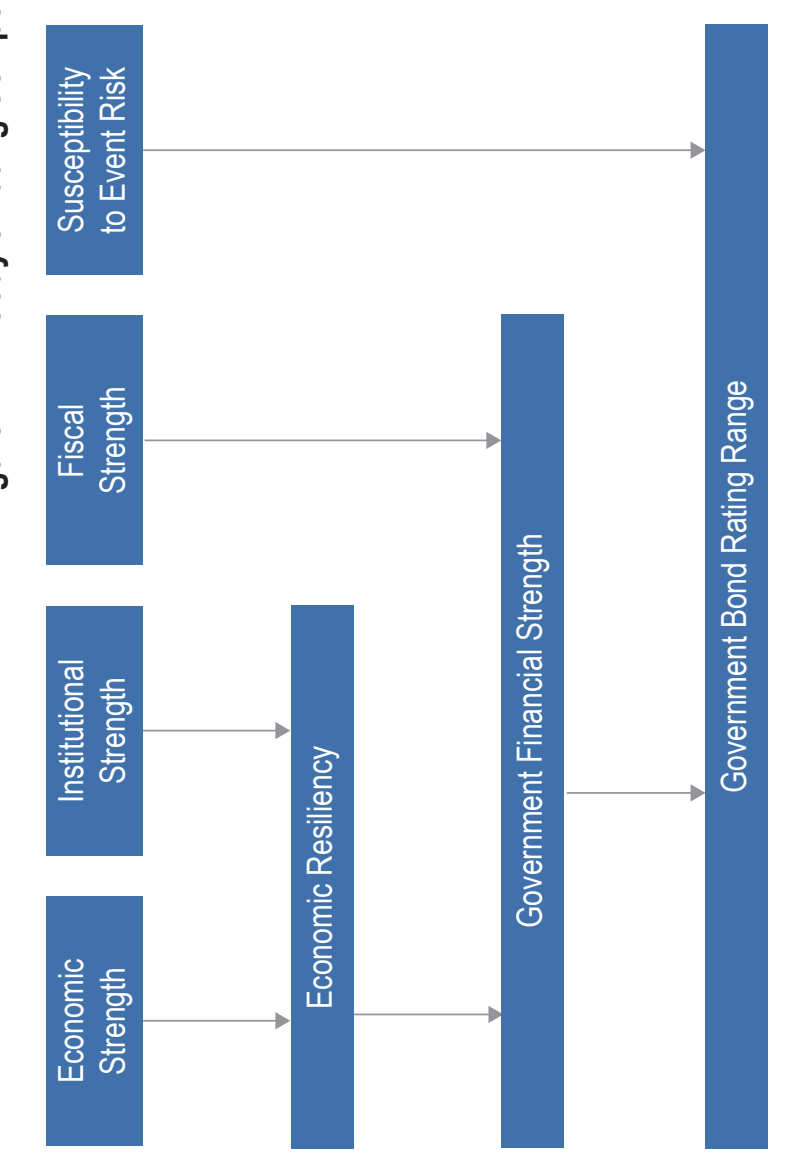


financial strength assessment using a double entry table (bottom left panel of Figure 14). Finally, the alpha-numeric rating is obtained by using a double entry table that combines the government financial strength assessment with the event risk assessment (bottom right panel of Figure 14).

To assign scores to the individual factors, Moody's analysts start with quantitative indicators with preassigned weights and then use a qualitative analysis to adjust the score by a maximum of 6 points. Moody's considers control of corruption to be an important driver of creditworthiness:

The transmission channels of institutional corruption vary. This can negatively affect a country's economic performance through the misallocation of resources that, in its absence, would have been assigned to more economically efficient uses. It also hinders productivity in the private sector by distorting economic incentives and introducing additional financial burdens to business activities.

In the public arena, corruption can also affect government finances. This could take the form of tax revenue loss due to evasion. Additionally, corruption can have a direct impact on public spending. In a case where public funds originally intended to be used for infrastructure projects were misappropriated, public expenditures are artificially increased, making these less efficient. This in turn would lead to higher borrowing by the government, negatively impacting its debt metrics (Moody's, 2017a: 3).

Moody's institutional strength assessment includes two subfactors plus a qualitative adjustment factor. The two subfactors are "institutional framework and effectiveness" (with a weight of 75 percent) and "policy credibility and effectiveness" (25 percent weight). The $\mathrm{WCl}$ is one of the three indicators that contribute to the institutional framework and effectiveness subfactor (the other two are the Worldwide Rule of Law Index and the Worldwide Government Effectiveness Index). However, the three indicators do not have the same weight. The Government Effectiveness Index has a weight of 50 percent and the other two indicators each have a weight of 25 percent. Therefore, control of corruption has a 19 percent weight (one-quarter of 75 percent) in the institutional strength factor. $A$ control of corruption score greater that 1.03 is associated with a $\mathrm{VH}+$, and a control of corruption score lower than -0.9 is associated with a VL- evaluation.

According to Moody's (2017a), corruption remains a challenge for sovereign credit profiles across Latin America. The median score for the 22 IDB borrowing countries rated by Moody's in 2015 was -0.49 (corresponding to an evaluation of $L$ ) and the average score was -0.17 (corresponding to an evaluation of $\mathrm{M}+$ ). A one standard deviation improvement in this indicator would bring the median country to $0.51(\mathrm{H}+$ score $)$ and the average country to 0.83 ( $\mathrm{VH}$ score, the second highest category). Among IDB borrowing countries, only the Bahamas, Barbados, Chile, Costa Rica, and Uruguay receive a $\mathrm{VH}+$ score in the control of corruption methodology; most countries in the LAC region are in the low to very low range. Paraguay and Venezuela (VL-) have the lowest scores in the region, followed by Nicaragua (VL), Bolivia, Dominican Republic, Ecuador, Guatemala, Mexico (VL+), Argentina, and Peru (L-).

Mexico and Peru have a relatively high credit rating (A3) and low scores in the control of corruption indicators. It is thus possible that high levels of corruption are an important constraint 
for these countries' credit ratings. ${ }^{19}$ In other words, it may be easier to increase the rating of these countries by addressing the corruption problem rather than addressing other drivers of the credit rating under which these countries are already performing well.

\subsection{Fitch}

At Fitch, the rating process consists of three steps that use a combination of a quantitative model (the Sovereign Rating Model, or SRM, which includes 18 indicators grouped into four analytical pillars) and a series of qualitative judgments (Fitch, 2016: Appendix 2).

In the first step, Fitch analysts use the quantitative model to determine a preliminary score for each of the four analytical pillars. This step is based on the variables and weights described in Table 11.

The second step consists of adjusting each of the four preliminary scores with a qualitative overlay which is designated to control for factors that are not fully captured by the quantitative indicators included in the SRM. This adjustment can potentially modify the score of each pillar by $+2 /-2$ notches. However, the overall maximum adjustment relative to the total SRM score is capped at $+3 /-3$ notches. Therefore, the methodology does not allow the maximum adjustment to each of the analytical pillars to be applied. In the third step, the scores of the four analytical pillars are added in to a total score that determines the rating; Table 12 provides an example.

As the SRM assigns a 10 percent weight (18.7 percent of 53.6 percent) to the simple average of the six WGIs, the WGI control of corruption
Table 11: Indicators and Weights in Fitch's SRM

\begin{tabular}{lc}
\hline Analytical pillars and indicators & Weight \\
\hline Structural & 53.6 \\
\hline Governance indicators & 18.7 \\
\hline GDP per capita & 15.1 \\
\hline Share in world GDP & 12 \\
\hline Years since default & 5.3 \\
\hline Money supply/GDP & 2.5 \\
\hline Macroeconomic performance, policies, and prospects & 11.8 \\
\hline Real GDP growth volatility & 4.7 \\
\hline CPI inflation & 3.7 \\
\hline Real GDP growth & 3.4 \\
\hline Public finances & 16.7 \\
\hline Government debt/GDP & 6.7 \\
\hline Government interest/revenues & 4.0 \\
\hline Government fiscal balance/GDP & 3.7 \\
\hline Foreign currency government debt/total & 2.3 \\
\hline government debt & 17.9 \\
\hline External finances & 8.5 \\
\hline Reserve currency flexibility & 4.2 \\
\hline Sovereign net foreign assets & 2.1 \\
\hline Commodity dependence & 1.4 \\
\hline Foreign exchange reserves & 0.5 \\
\hline External interest service & \\
\hline Current account balance + FDI/GDP & 1.3 \\
\hline Soure:Auth's anlssi of & \\
\hline
\end{tabular}

Source: Author's analysis of Fitch methodology.

indicator has an implicit weight of 1.7 percent in the baseline (before the qualitative adjustment) rating opinion of Fitch.

To express in quantitative terms the importance of WGI's corruption indicators in Fitch's rating methodology, consider the following example. In

\footnotetext{
${ }^{19}$ Simulating the effect of an increase in the control of corruption score requires the Moody's scores for all other elements in the methodology. Unfortunately, this information is not publicly available.
} 


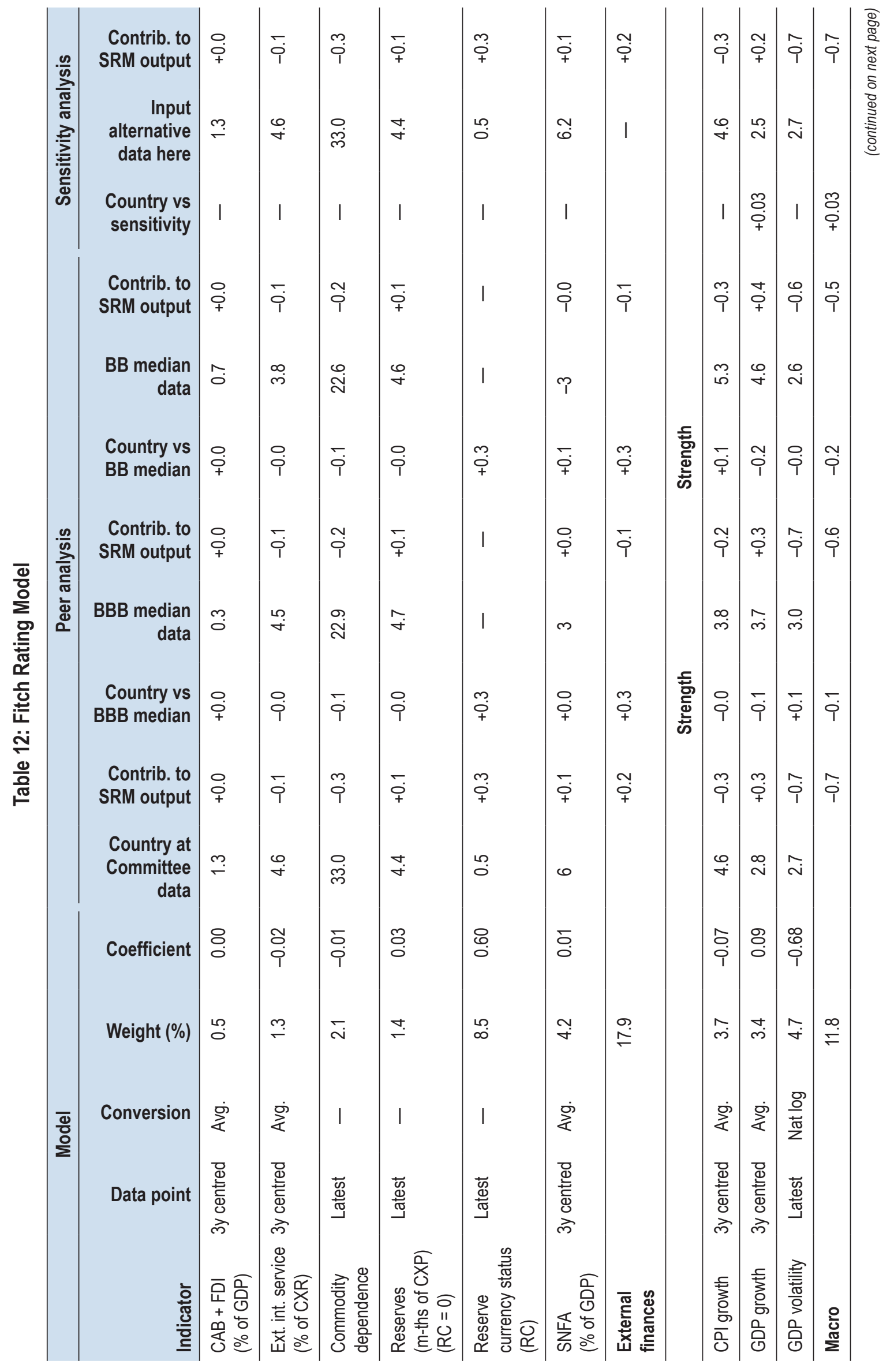




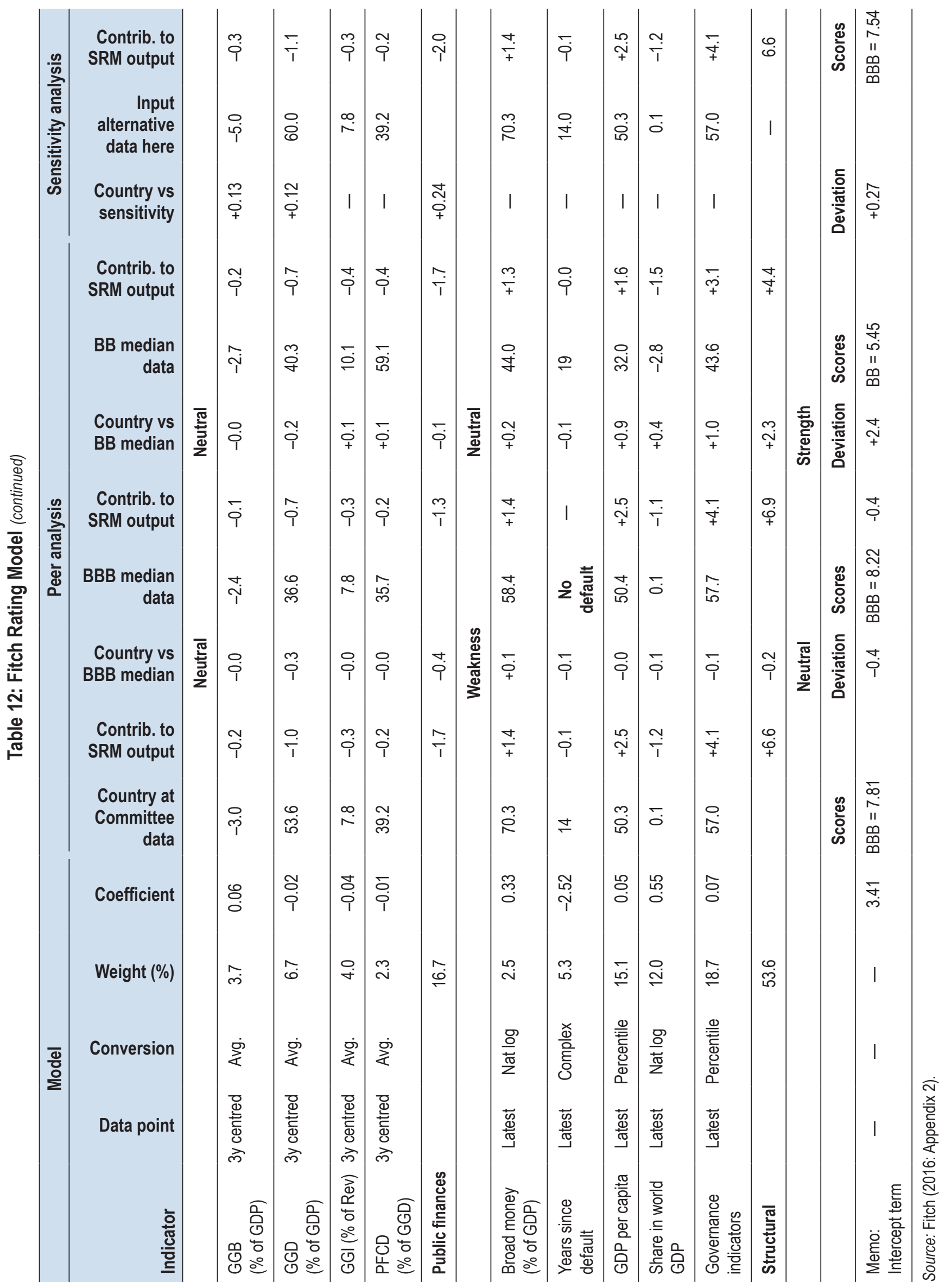


2016, Fitch rated 19 IDB borrowing countries. Their ratings ranged between $\mathrm{CCC}$ and $\mathrm{A}+$ with median (and mean) rating of BB. The median value of the WGI control of corruption indicator for this sample of countries in 2015 (data for 2016 are not available) was -0.56 (the mean value was -0.33 ), corresponding to the 35 th percentile of the worldwide distribution of this indicator (the mean value corresponds to the 47 th percentile of the distribution).

What matters for the overall Fitch score is the distribution of the simple average of the six WGIs. Fitch (2016: Appendix 2) shows that a 1 percent increase in the WGI ranking leads to an increase of 0.07 points in the baseline rating. The median IDB borrowing country is at the 49th percentile of the overall WGI distribution, and the average IDB borrowing country is at 52 percent of the overall distribution (the median and average IDB borrowing country does relatively worse in corruption than in the other governance indicators). A one-standard-deviation increase of the corruption indicator would place the median IDB borrowing country at the 69th percentile of the distribution of this indicator and the average IDB borrowing country at the 77 th percentile of the distribution. Other things being equal, such an improvement of the corruption indicator would move the median IDB borrowing country to the 56th percentile of the distribution of the WGI indicators and the average country to the 58th percentile. Summing up, a onestandard-deviation increase of the corruption indicator would lead to 7-point increase in the overall ranking of the governance indicators and an improvement of 0.49 points (or half a notch) in the sovereign rating. 



\section{CONCLUSIONS AND SUGGESTIONS FOR FURTHER WORK}

A wave of corruption scandals and increased political uncertainty has led to market turmoil and currency instability in many large emerging market countries. Rating agencies took note of these developments. Since the beginning of 2014, Standard \& Poor's, Moody's, and Fitch have issued more than 150 negative rating actions for emerging market sovereigns. ${ }^{20}$ In April 2017, Standard \& Poor's downgraded South Africa's debt. Three of the five BRICS countries are now rated below investment grade by at least one major agency. China and India still have an investment grade rating, but while India has a stable outlook, Moody's downgraded China's rating in May 2017.

Corruption scandals and the associated political instability also led to changes in Brazil's rating outlook. On May 23, 2017, Standard \& Poor's placed Brazil's debt on credit watch with negative implications (meaning that the country could be downgraded in the next three months). The main rationale for this rating action was that "the political dynamics in Brazil have worsened following recent allegations of corruption against President Michel Temer during the course of the ongoing Lavo Jato investigations." ${ }^{21}$ On May 26, Moody's followed suit and changed Brazil's outlook to negative from stable. The change in outlook was also motivated by recent political events. Specifically, Moody's stated that the first driver for the change in outlook was the "rise in uncertainty regarding reform momentum following recent political events." 22

This paper shows that there is a strong conditional and unconditional correlation between ratings issued by Standard \& Poor's, Moody's, and Fitch and three commonly used corruption indicators. The paper also shows that the main rating agencies incorporate corruption indicators in their rating criteria, but that there are important differences in the way in which corruption indicators affect the ratings issued by these three agencies.

OECD (2014) lists four main costs of corruption: (i) it increases the cost of doing business; (ii) it leads to waste or the inefficient use of public resources; (iii) it excludes poor people from public services and perpetuates poverty; and (iv) it corrodes public trust, undermines the rule of law, and ultimately delegitimizes the state. In this regard, In this regard, there are several avenues for future research. First, it would be interesting to explore if the link between corruption and ratings varies across countries and to study whether corruption is a more important

\footnotetext{
${ }^{20}$ http://www.cnbc.com/2017/05/24/reuters-america-china-downgrade-shows-emerging-market-ratings-stuck-in-reverse.html

${ }^{21} \mathrm{https}$ ://www.globalcreditportal.com/ratingsdirect/renderArticle.do?articleld=1853853\&SctArtld=425928\&from=CM\&nsI_code=LIME\&sourc eObjectld=10105696\&sourceRevld=3\&fee_ind=N\&exp_date=20270523-06:33:22

22 https://www.moodys.com/research/Moodys-changes-outlook-on-Brazils-Ba2-issuer-rating-to-negative--PR_367210
} 
constraint for certain countries. Consider, for instance, four types of countries: (i) those with good control of corruption scores and investment-grade ratings (e.g., Chile); (ii) those with low control of corruption scores and investmentgrade ratings (e.g., Mexico and Peru); (iii) those with good control of corruption scores and below-investment-grade ratings (e.g., Barbados); and (iv) those with low control of corruption scores and below-investment-grade ratings (there are many countries in this group).

Countries that belong to the first group are doing relatively well in all aspects. They have good macroeconomic fundamentals and strong institutions, and it is not obvious that, in an attempt to improve their ratings, they should focus on a specific aspect like control of corruption. Similarly, countries that belong to the fourth group are doing relatively poorly on all aspects and should improve both their macroeconomic and institutional fundamentals. Countries that belong to the third group have strong institutions but weak macroeconomic fundamentals (e.g., Barbados has high debt and a large current account deficit). In this case, fixing the macroeconomic fundamentals should be the priority. Finally, in the countries that belong to the second group, which are characterized by good macroeonomic fundamentals and poor institutions, there may be large returns associated with policies aimed at improving the institutional environment and reducing corruption. These potentially high returns can arise from the fact that small policy improvement have larger effects when countries are far from the efficiency frontier (i.e., there are decreasing returns in specific economic policies) and from the fact that there are nonlinearities in the rating methodologies of Moody's and Standard and Poor's. Specifically, it may be difficult to improve the macroeconomic environment when a country is already doing relatively well in this aspect. It may, instead, be easier to reduce corruption if the country is far from the frontier. Moreover, the presence of nonlinearities in rating methodologies may lead to a situation in which a relatively small change in one rating component may have a large effect on the overall credit rating. These nonlinearities are likely to be important when a country severely underperforms on a given indicator.

In the presence of nonlinearities, evaluating country-specific payoffs of improved control of corruption scores would require recreating the sovereign ratings of countries with low institutional quality and then simulating how changes in the control of corruption score affect the overall rating. This is a time-consuming but straightforward exercise that could become part of the toolbox of debt management offices and international financial institutions.

A second avenue for future research relates to improving understanding of what corruption indicators actually measure and of how these indicators relate to other measures of institutional quality. This paper shows that, besides being significant from a purely statistical point of view, the correlation between corruption and ratings is also economically significant. The statistical analysis in Tables 3-5 suggests that a one-standard-deviation change in control of corruption is associated with an increase of 2.5 notches in credit ratings. This correlation is much larger than the estimated effect of a standard deviation change in the debt-to-GDP ratio, current account balance, or inflation. However, the paper also shows that control of corruption is closely correlated with other governance indicators and that it is almost impossible to separately estimate the effect of individual governance indicators. ${ }^{23}$

\footnotetext{
${ }^{23}$ In technical parlance, the statistical model suffers from a multi-collinearity problem.
} 
Moreover, the expert assessments used by the main rating agencies are weakly correlated with actual data on corruption victimization, and they are more likely to reflect the experts' overall views of a country's institutional situation rather than being specifically focused on corruption problems. ${ }^{24}$ This approach makes sense because the effects of anti-corruption policies are likely to be short-lived in a country with generally weak institutions. The implication is that anti-corruption campaigns need to be part of an integrated process of institutional improvement. ${ }^{25}$

A third avenue for future research relates to how rating agencies treat corruption scandals and anti-corruption campaigns more generally. Recent evidence suggests that such scandals have a negative effect on ratings because they increase political instability and bring corruption problems to the forefront. However, rating agencies may also consider corruption scandals as positive developments, with the potential for decreasing corruption in the long run (Moody's, 2017a).
Along similar lines, anti-corruption campaigns can increase the salience of corruption and possibly lead to a short-term decrease in the control of corruption score but could also yield longterm benefits. ${ }^{26}$ It would be interesting to study whether the rating agencies incorporate these potential long-term benefits into their assessment of sovereign risks by building a database of anti-corruption campaigns and corruption scandals and following countries over time to gauge how corruption indicators and rating agencies respond to these events in terms of both magnitude of their changes and time lags. In this setting, it would be particularly interesting to test whether during and after these types of events the response of rating agencies deviates from that of the standard corruption indicators. Finally, a systematic study of the evolution of the methodologies of the main rating agencies could increase understanding of whether concerns about corruption have become more important over time and what specific events may have affected the way in which agencies incorporate considerations of corruption into their methodologies.

\footnotetext{
${ }^{24}$ It would be interesting to study whether these indicators assign different weights to different types of corruption. For instance, do these expert assessments give different weights to illegal behavior of roving and stationary bandits (Olson, 2000)?

${ }^{25}$ Moody's institutional effectiveness measure assigns a 50 percent weight to the government effectiveness indicator, a 25 percent weight to the control of corruption indicator and a 25 percent weight to the rule of law indicator. It is not clear why the agency chose this particular weighting scheme or why the methodology of Moody's and Fitch use the WGI governance (and corruption) indicators rather than using other governance indicators.

${ }^{26}$ These benefits will depend, again, on the quality of the overall institutional environment, which will affect the intensity and credibility of the policy and of the judicial response.
} 



\section{REFERENCES}

Amato, J. and C. Furfine. 2004. "Are Credit Ratings Procyclical?" Journal of Banking \& Finance, 28: 2641-77.

Bar-Isaac, H. and J. Shapiro. 2013. "Ratings Quality over the Business Cycle." Journal of Financial Economics, 108(1): 62-78.

Broto, C. and L. Molina. 2016. "Sovereign Ratings and their Asymmetric Response to Fundamentals." Journal of Economic Behavior \& Organization, 130: 206-24.

Butler, A. and L. Fauver. 2006. "Institutional Environment and Sovereign Credit Ratings." Financial Management, 35: 53-79.

Cantor, R. and F. Packer. 1996. "Determinants and Impact of Sovereign Credit Ratings." NY Fed Economic Policy Review, 2(2): 37-53.

Depken, C. and C. LaFountain. 2006. "Fiscal Consequences of Public Corruption: Empirical Evidence from State Bond Ratings." Public Choice, 126: 75-85.

Depken, C., C. LaFountain, and R. Butters. 2011. "Corruption and Creditworthiness: Evidence from Sovereign Ratings." In R. Kolb (ed.). Sovereign Debt. New York, NY: John Wiley \& Sons.

Donchev, D. and G. Ujhelyi. 2014. "What Do Corruption Indices Measure?" Economics and Politics, 26: 309-331
Eichengreen, B., R. Hausmann, and U. Panizza. 2003. "The Pain of Original Sin." In Eichengreen and Hausmann (eds.). Other People's Money: Debt Denomination and Financial Instability in Emerging Market Economies. Chicago, IL: University of Chicago Press.

2007. "Currency Mismatches, Debt Intolerance, and the Original Sin: Why They are Not the Same and Why It Matters." in S. Edwards (ed.) Capital Controls and Capital Flows in Emerging Economies: Policies, Practices and Consequences. Chicago, IL: University of Chicago Press.

Fitch. 2016. "Sovereign Rating Criteria." London, UK: Fitch Ratings. Available at: https://www.fitchratings.com/site/re/885219.

Kaufmann, D., A. Kraay, and M. Mastruzzi. 2011. "The Worldwide Governance Indicators: Methodology and Analytical Issues." The Hague Journal of Rule of Law, 3(2): 220-46.

Kenny, C. 2009. "Measuring Corruption in Infrastructure: Evidence from Transition and Developing Countries." The Journal of Development Studies, 45: 314-32.

Kiff, J., M. Kisser, and L. Schumacher. 2013. "Rating Through-the-Cycle; What does the Concept Imply for Rating Stability and Accuracy?" IMF Working Papers 13/64. Washington, DC: International Monetary Fund. 
Löffler, G. 2004. "An Anatomy of Rating through the Cycle." Journal of Banking \& Finance, 28: 695-720.

Moody's. 2016. "Rating Methodology: Sovereign Bond Ratings." Moody's Investors Services. December 22.

Moody's. 2017a. "Odebrecht Case Illustrates Pervasiveness of Corruption, But Could Prompt Reform." Moody's Investors Services, May 16.

2017b. "CDO Research Data Feed Glossary of Terms." Moody's Investor Services. Available at: https://www.moodys.com/sites/products/ProductAttachments/ CDOGlossary.pdf

Mora, N. 2006. "Sovereign Credit Ratings: Guilty beyond Reasonable Doubt?" Journal of Banking \& Finance, 30(7): 2041-62.

Morris, S. 2008. "Disaggregating Corruption: A Comparison of Participation and Perceptions in Latin America with a Focus on Mexico." Bulletin of Latin American Research, 27: 388-409.

OECD (Organisation for Economic Co-operation and Development). 2014. "The Rationale for Fighting Corruption." Background brief. Paris: OECD. Available at: https://www. oecd.org/cleangovbiz/49693613.pdf.
PRS Group. Undated. "ICRG Methodology." Available at: http://www.prsgroup.com/ about-us/our-two-methodologies/icrg

Olson, M. 2000. Power and Prosperity: Outgrowing Communist and Capitalist Dictatorships. New York, NY: Basic Books.

Razafindrakoto, M. and F. Roubaud. 2010. "Are International Databases on Corruption Reliable? A Comparison of Expert Opinion Surveys and Household Surveys in SubSaharan Africa." World Development, 38: 1057-69.

Standard \& Poor's. 2014. "Sovereign Rating Methodology." Standard \& Poor's Rating Services, December 23.

2017. "Sovereign Rating Methodology." Standard \& Poor's Rating Services, April. Available at: http://media.spglobal. com/documents/SPGlobal_Ratings Article 13+April+2017 Annual+Corporate+ Default+Study+and+Rating+Transitions.pdf

Svensson, J. 2005. "Eight Questions about Corruption." Journal of Economic Perspectives, 19: 19-42.

Transparency International. 2012. "Corruption Perceptions Index 2012: An Updated Methodology." Available at: https://www. transparency.org/files/content/pressrelease/2012 CPIUpdatedMethodology EMBARGO EN.pdf 



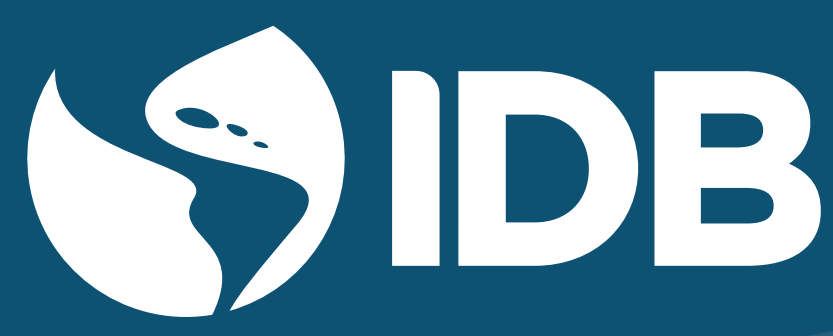

